HEALTH PHYSICS ENVIRONMENTAL MONITORING

\author{
Semiannual Report, \\ January through June 1962
}

$\circ$

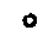

$\circ$

$\circ$
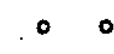

\title{
February 1963
}

:

Written and approved December 1962 ;

Issued February 1953

E. I. du Pont de Niemours anà Company

Explosives Department - Atomic Energy Division

Savannah River Plant

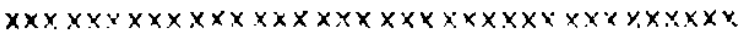

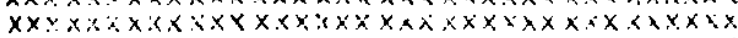

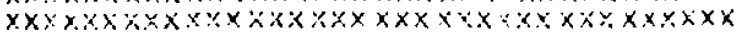

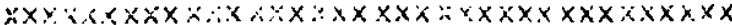

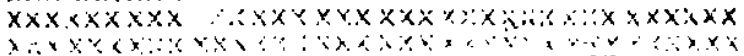

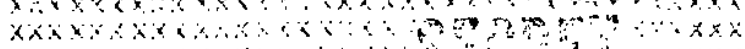




\section{Distribution}

\section{Wilmington}

I M. H. Smith

2 J. B. Tinker

$3 \mathrm{H}$. Worthington

4 W File

\section{Savannah River Plant}

5 J. D. Ellett -

J. A. Monier, Jr.

6 W. P. Bebbington

7 R. B. Fenninger

8 F. H. Endorf

9 K. W. Millett

$10 \mathrm{~K} . \mathrm{W}$. French

11 F. E. Kruesi

12 E. B. Sheldon

I.3 J. K. Lower

14 L. G. Ahrens

15 P. A. Dahlen

16 P. R. Moore -

W. E. Egan

17 C. M. Patterson
18 P. B. K'Burg

19 W. C. Reinig

20 H. A. McClearen

21,22 E. C. Morris

23 H. L. Butler

24 D. C. Nichols

25 J. H. Eorton

26 W. L. Marter

27 J. E. Johnson

28 W. P. Overbeck

29 J. W. Morris

30 D. E. Waters

33 TIS File

34 TPO FiIe

35-45 PED Fxtra Copies

46 PED Recorit Copy

\section{Atomic Energy Commission}

31 P. J. Hagelston, SROO

32 I. A. Hobbs, SROO 


\section{Contents}

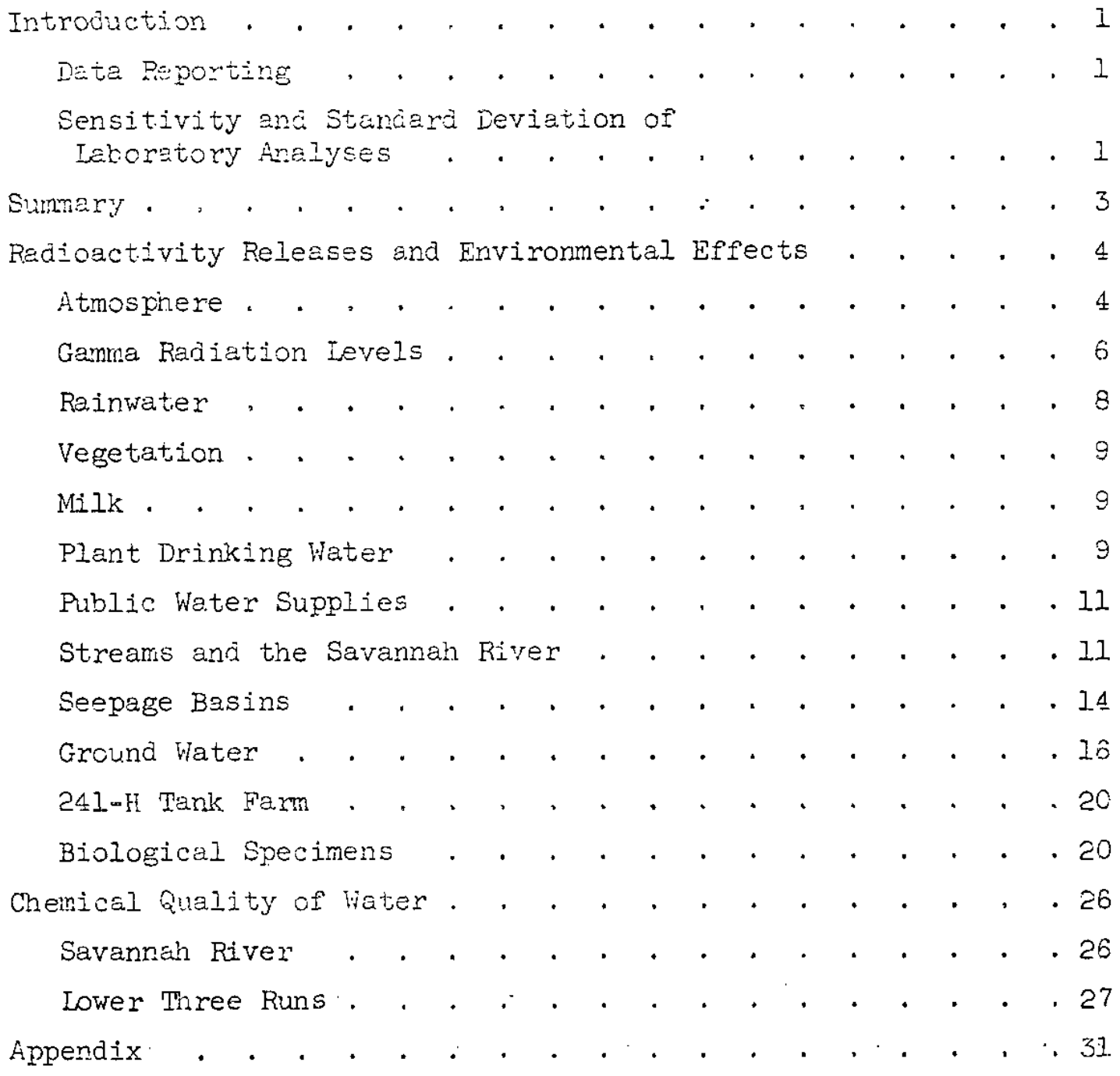

\section{Abstract}

Radioactivity in the environs of the Savannati River Plant was measured during the six-month period ending June 30, 1962. Fallout from nuclear weapons testing was evident in nearly all phases of the regional monitoring program. Atmospheric samples showed no filterabie beta activity above levels attributable to bomb fallout. Releases of radioactive materials to the atmosphere and to separations Areas seepage basins increased sijgitly. Increases from Reactor Area to Plant streams were associated with a fueI element iajlure and the recognition of sulfur-35 in releases during routine reactor discharges. Radioiodine releases resulting from discharge of the failed element were detectable for a sinort time in the Savannah River. 


\section{Introduction}

Under a procram established by the Lu Pont Company in June 1951, the Savennain River Plant site and surrounding region are systematically monitored for radioactivity. Results of the environmental moritoring Erogrem prorice information useful zoth as a measure of the effectiveness of Plant controls and as an authcritative record of environmental conàtions.

Period Covered: January through June 1962.

\section{Data Reporting}

Survey data were averaged for the 6-month period and compared with the previous 6-month averages ("Health Physics Regional Monitoring Semiannual Report," DPSP 62-25-9, May 1962). "Avg" or "Total" refers to the average or total for the current period and "Prev Avg". or "Prev Total" refers to the average or total for the preceding 6-month period. Urless otherwise speuified, "Max" refers to the greatest concentration observed in a single sample collected during the report period:

\section{Sensitivity and Standard Deviation of Laboratory Aralyses}

Sensitivity of laboratory analyses rerers to the minimum amount of radioactivity that can be detected by radiochemical analytical techniques used. It is based on statistical counting error ( $90 \%$ confidence level) and is influenced by sample size, counter efficiency, and counter background. No self-absorpticn corrections have been applied to the alpha and nonvolatile beta results. The standara deviations shown in the table on page 2 were calculated from spike recovery values. They apply to the 6-month averages of data in this report.

Where samples were analyzed by gamma spectrometry, the lower level of detection of a given isotope varied with: (1) background of each individual channel grouping and (2) geometry and volume of 
sample analyzea. For this reason, no average senitivities are given. Furthermore, no differentiation ras made between nuclides emitting farma rays of nearly the same energy. Thus, data are re-

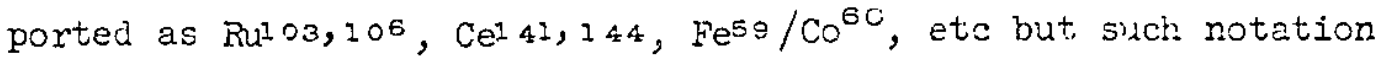
does not mean that both isotopes were necessarily present. The differentiaticn betreen isotopes in most such groupings can be made, if requirea, by approximate age estimates of the radioactive material at the time of release, chemical separations, and decay and beta absorption studies.

\begin{tabular}{|c|c|c|c|c|}
\hline Analysis & Samples & Sensitivity & $\begin{array}{c}\text { Standard } \\
\text { Deviation, }\end{array}$ & Spike Value \\
\hline \multirow[t]{4}{*}{ Alpha } & Water & $0.22 \pm 0.12 \mu \mu \mathrm{c} / \mathrm{l}$ & 9 & $45 i+f d \ell$ \\
\hline & Mud & $0.22 \pm 0.12 \mu \mu \mathrm{c} / \bar{B}$ & - & - \\
\hline & Vegetation & $0.11 \pm 0.06 \mathrm{H}$ & - & - \\
\hline & Air & $0.04 \pm 0.02 \times 10^{-2} \mu \mu \mathrm{c} / \mathrm{ma}$ & - & - \\
\hline \multirow[t]{5}{*}{ Beta } & Water & $4.2 \pm 0.3 \mathrm{\mu Lc} / 2$ & - & - \\
\hline & Mud & $4.2 \pm 0.3 \mu \mu \mathrm{c} / \mathrm{g}$ & - & - \\
\hline & Vegetation & $2.1 \pm 0.2 \mu \mu \mathrm{c} / \mathrm{B}$ & - & - \\
\hline & $\begin{array}{r}\text { Biclogical } \\
\text { Specimens }\end{array}$ & $2.0 \pm 0.1 \mathrm{H \mu c} / \mathrm{g}^{*}$ & - & - \\
\hline & Air & $0.6 \pm 0.04 \times 10^{-2} \mathrm{wuc} / \mathrm{m}^{3}$ & - & - \\
\hline \multirow[t]{3}{*}{ TBP Extraction } & inter & $0.20 \pm 0.25 \mathrm{nLc/2}$ & 20 & $45+\mu c / 2$ \\
\hline & Mud & $0.34 \pm 0.19 \mu \mathrm{\mu c} / g$ & 25 & $45 \mu H \mathrm{c} / \mathrm{s}$ \\
\hline & Vegetation & $0.03 \pm 0.02 \mu \mu \mathrm{c} / \mathrm{g}$ & 10 & $4.5 \mu \mu \mathrm{C} / \mathrm{g}$ \\
\hline \multirow[t]{4}{*}{ Radioiodine } & Water & $9.3 \pm 0.7 \mu \mathrm{Hc} / \ell$ & 9 & 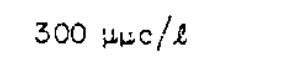 \\
\hline & Vegetation & $0.2 \pm 0.02 \mu \mathrm{Hc} / \mathrm{s}$ & - & - \\
\hline & Air & $1.8 \pm 0.2 \times 10^{-2}$ whe $/ \mathrm{mB}$ & - & - \\
\hline & Milk & $2.2 \pm 0.2 \mu \omega c / 2$ & 10 & $200 \mu \omega c / 2$ \\
\hline \multirow[t]{2}{*}{ Tritium } & Water & $3000 \pm 200 \mu \mathrm{\mu l} / \ell$ & 3 & $2500 \times 10^{3} \mathrm{H} \mathrm{c} / \ell$ \\
\hline & Air & $60 \mathrm{H} \mathrm{c} / \mathrm{m}^{3} * *$ & - & - \\
\hline Radiocesium & Water & $4.3 \pm 0.3 \mu \mathrm{uc} / 2$ & 9 & $600+4 \mathrm{LC} / \mathrm{l}$ \\
\hline Radiostrontium & Water & $6.4 \pm 0.4 \mathrm{H} \mu \mathrm{c} / \mathrm{l}$ & 7 & $230 \mu \mathrm{\mu Lc} / 2$ \\
\hline \multirow[t]{2}{*}{ Strontium-90 } & Water & $0.1 \pm 0.01 \mu \mathrm{iuc} / \hat{k}$ & 8 & $230 \mu \mu_{c} / \ell$ \\
\hline & Milk & $1.6 \pm 0.1+\mathrm{H} / \mathrm{c} / 2$ & 7 & $47 \mathrm{iLc/2}$ \\
\hline
\end{tabular}


Summary

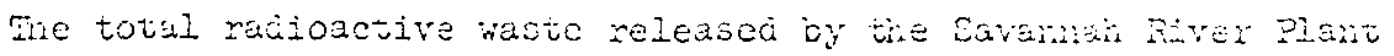
into the atmosphere, efîluent streams, and earthen seepage basins curing the 6-montin period is shown in the following tabie. Radioactivity discirarged to effluent streams does not reilect miscellaneous releases of tritiun (ie, P-Area cooling water, heat exchanger leakage - noderator to cooling water, sump discharges, etc).

$\begin{array}{ccc}\text { Atmosphere } & \text { Effluent Stream } & \text { Seepage Pasin } \\ 12.2 & 116.5 & 778 \\ 1.8 & 561.5 & 1,36 \\ 7.3 & 82.1 & 3.5 \\ 454.2 & 25.3 & 16.6\end{array}$

Disciarge of nonvolatile beta from F-Area stack increased ll-fold over the previous 6-montin period due to resumption of the Purex process. Nonvolatile beta discharged from 9-fold after suspension of the him process anci a decrease in the release of resiaual ruthenium, unusually high in i.96l. The net increase over the previous 6raonth periou was 0.9 curies.

Sersitive indicators of environtiontal contamination (rain, aix, vegeiation, and milk) showed similicunt evicicree of fallout from nuclear weapons testing. Unlike sallout from the Soviet tests in 1961 wiren sudden, substantial increases of ronvolatile beta and radioiodine were seen, fallout from U. S. atnospheric tests in May and June was detected as nonuniform, low-level I-13I concentrations in environmental samples. The estinated cumulative infant thyroid dose from consumption of iodine contaminated milk from local dairies was $3 \%$ of the annual limit of 500 mrem recommended by the Foderal Radiation Council. Low-level radioiodine and tritium concentrations in air were detected on occasion in $F$ and A Areas in conjunction with local releases. No nonvolatile beta concentraitions above levels attributable to bomi fallout were detected in the atmosphere either on or of $f-P l a n t$. 


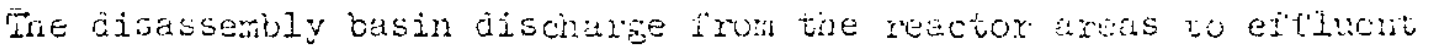
strears (381 curies, exclusive of $8-35$ and tritibri) rapesented a

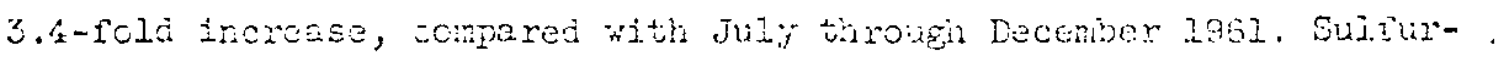

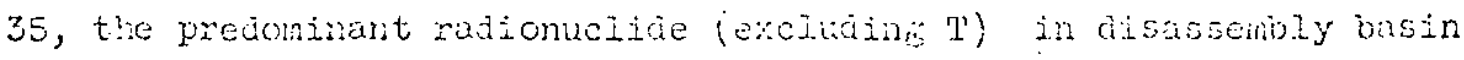
water, totaled 262 curies. The largest single release incicient was in P Ares curing May, wher 203 curies reve roleased to Stesl Crect following disciare of a failed fuel element. Racioiodine was readily detectable in stram and river watex after the inciaent. Plant-released alpha activity had neglifible effect on concentrations of alpha activity in stream water and was generaily detectable only in low volume effluenti from the 300,700 , and 200 Artas.

Fallout from nuclear tests was evident in river water throughout the report period. Plant-contributed radioactive materials in transport in the river at the Highway 301 crossing totaled oo curies of nonvolatile beta and 30,300 curies of tritiim.

Uptake of PLant-released radjoactivity by Savanah River fish was generilly confired to low level concentrations of radiostrontium in the bores. However, a few river fish also contained low level concentrations of $\mathrm{Cs}-1.37$ and $\mathrm{Zn}-65$ ir both the hores and Illeshy tissues. Highex concentrations of these radionuclides were present in reactor effluent fish. Waterfonl from Pai Pond and terrestrial animals from the Plant site contaned low level concentrations of nonvolatile beta emitters in the bones and fleshy tissues. Radio. iodine from nuclear tests was detected in the thyroid glands of both waterfowl and terrestrial specinens.

\section{Radioactivity Releases and Environmental Effects}

\section{Armosphere}

Releases of racioactive materials from ixdividual Plant areas to the atmosple re during this period are compared to releases during the Irevious 6-month period in the following table. Individual. isotopes comprisinfs $F$ and $H$-Area nonvolatile beta totals are in Appendix A, table 2 . 


\begin{tabular}{|c|c|c|c|c|c|c|c|c|}
\hline \multirow[b]{3}{*}{ Area } & \multicolumn{2}{|c|}{ Alpha: ine } & \multicolumn{2}{|c|}{ Noniolat Le Eeta, roc } & \multicolumn{2}{|c|}{ Radioiodine, } & \multicolumn{2}{|c|}{ Fritium, $c$} \\
\hline & & Frey & & Prev & & $P l \in V$ & & Prev \\
\hline & Total & Totai & TotaI & Totai & Total & Total & TotaI & Total \\
\hline$F$ & 10.3 & 4.4 & $1 \equiv 20$ & 143 & 2.83 & 0.8 & .. & - \\
\hline H & 1.5 & 2.5 & 5.4 & 513 & $\therefore .47$ & 0.5 & $3<0, \approx 00$ & 332,400 \\
\hline R & - & - & 3.2 & 0.98 & - & - & 5,600 & 3,077 \\
\hline$P$ & - & - & 68 & 1.24 & - & - & 37,300 & 36,090 \\
\hline I & - & - & 4.5 & 1.66 & - & - & 26,000 & 21,673 \\
\hline $\mathrm{K}$ & - & - & 1.1 & 1.06 & - & - & 36,600 & 19,236 \\
\hline c & - & - & 1.2 & 1.06 & . & - & 25,900 & 16,175 \\
\hline TNX & - & - & 1.2 & 3.06 & - & - & 11 & 261 \\
\hline $773-A$ & 0.15 & 0.11 & 151.8 & 33 & 0.025 & 0.015 & 332 & 37 \\
\hline Total & 12.2 & 7.0 & 1808 & 695 & 7.32 & 1.3 & 454,243 & 434,283 \\
\hline
\end{tabular}

Discharge of nonvolatile beta from F-Area stack increased by a factor of Il over that during the preceding 6 months. 'This increase resulted from Purex process operation, January through June. OnIy aged SCRUP material was dissolved during the previous period. Eighty percent of the total release occurred during May and June in conjunction with the decresse in the effective age of the uranium dissolved near the end of the campaign. Ril 03,206 comprised $94 \%$ of the total 6-month release of nonvolatile beta emitiers.

The total nonvolatile beta discharged from H-Area stack decreased by a factor of 9 from the preceding 6-month period nximarily because of less ruthenium release (22 mc versus $420 \mathrm{me}$ ). Unusual releases of ruthenium (primarily $R$ l-106) occurring in the latter half of 1961 was attributed to residual deposits in the dissolver off-gas system. Reduction in releases of other nonvolatile beta isotopes resulted from the suspension of HM material dissolving.

$\because$ Stack releases of nonvolatile beta from $L$, $K$, and $C$ Areas (primarily $\mathrm{Ce} 21,144$, Rul 03, 106 , and $\mathrm{Zr}-\mathrm{Nb}^{95}$ ) were attributed to migration of fallout into ventilation systems. Releases from $R$ and $P$ Areas (predominantly Rul03, 105 ) were attributed to the effects of work on moderator piping duxing reactor containment outages. 


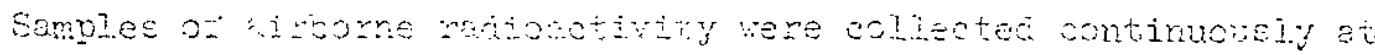

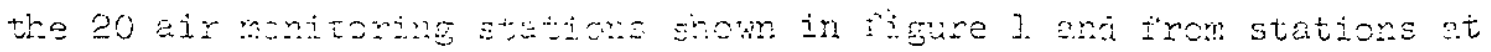

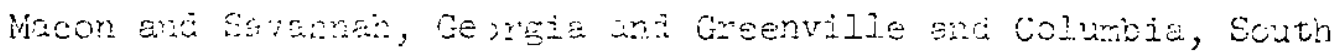
Carolina.

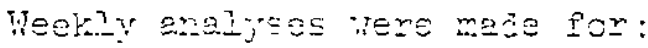

- Total alpha ano rilteraole beta (collected on HV 70 filter paper).

- Radiojouine (collectes on chancose centridiges).

- Tritium (in water vador coljected un silica gel columns).

Except for tritium, no airbome rajicactivity detected outside the Plant perimeter could be attributed to Plant releases. The maximum weekj.y concentration of tritium in air (1600 $H$ Area. As a result of nuclear tests, filterabie beta in air at a.1 sampling locations averaged $3.9 \mathrm{j \mu c} / \mathrm{m}^{3}$. (3.7 during the pre.. ceding repori period.) Following resumption of Soviet nuclear tests (September through December 1961) this concentration averaged $5.5 \mathrm{mic} / \mathrm{m}^{3}$ of air. With the exception of radioiodine, no increase in beta racioactivity in the atmoschere was discernable following the U.'S. noclear test series whici began in April 1962. Iow-Iavel concentrations of radioiodine, fixst detectea in the air luring the week ending kay 17 , continued throughout the report period. Concentrations of radioactive materiats in air are sumnarized in Appendix $B$, table $\perp$.

\section{Gamma Radiation Levels}

A summary of environmental garna dose rate measurements, made wi.th Landsverk L-55 pocket chambers and a modified I-60 electrometer, is given in Appendix B, table 2. No significant radiation leveis due to Plant operations were observed at the individual area perimeters or at the constant air monitor buildings. The highest average dose raie observed was $0.66 \mathrm{mr} / 24 \mathrm{hrs}$ at $300 / 700$ Area. Differerces in values silown are within the variation due to in-: strument response characteristics and nomal backiround iluctuations. 


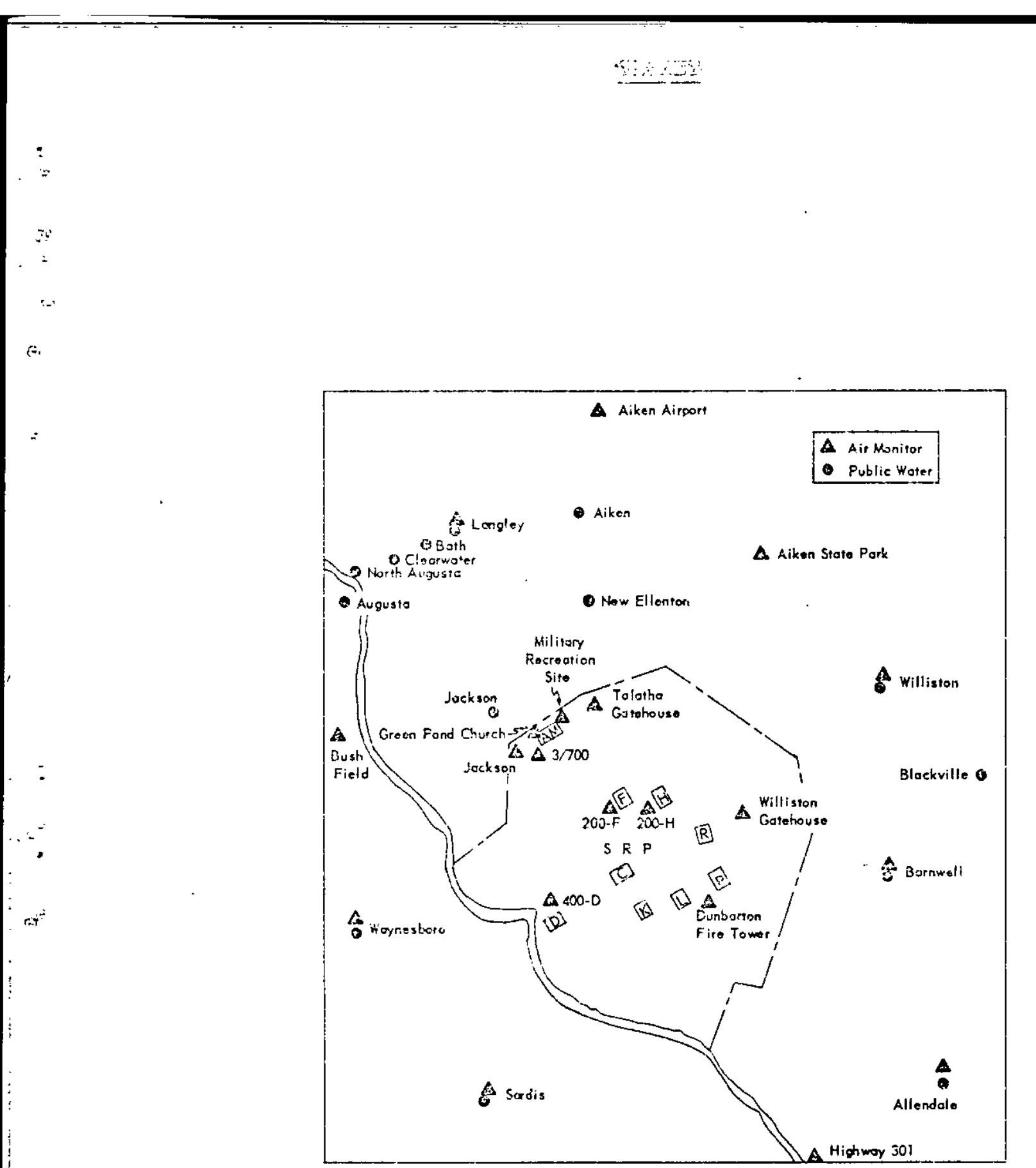

FICURE I. CONTINUOUS AIR MONITORING STATICNS AND PUBLIC WATER SAMPLING LOCATIONS 
Rainwate!

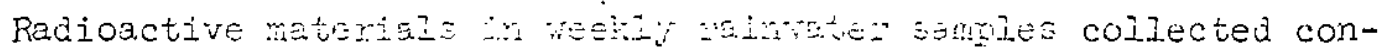
t.inuously at monitoning ztsticns siom in Pigure l are sumarized in Appenaix B, table 3 . Réioactivity jn rainvater consisted pri-

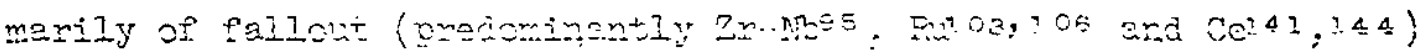
from nuclear tests. Nonvolatile bera in rainister during the 6month period averaged $1300 \mathrm{kw} / \mathrm{l}$ at the Piant perimeter and the 25 mile radius stations; the maximum observed in rainwater was $4300 \mathrm{H} \mathrm{c} / \mathrm{l}$. The vverage represerts $\approx 2.5$-fold increase over the average during tire previous 6 months. Tere was no significant increase in the concentration of nonvolatile beta emitters attributable to the U. S. tests.

Radicactive materials deposited on the Plant site in rainwater are shown in the following table. When no rain occurred, nonvolatile beta deposition was estimated from radioactivicy collected in an opan pan of water near Builaing $735 . \wedge$. The increased deposition of fallout vas due in part to more raires.l during the clirrent period than in the fall and winter of 1961.

\section{Radioactivity Deposition on Plent}

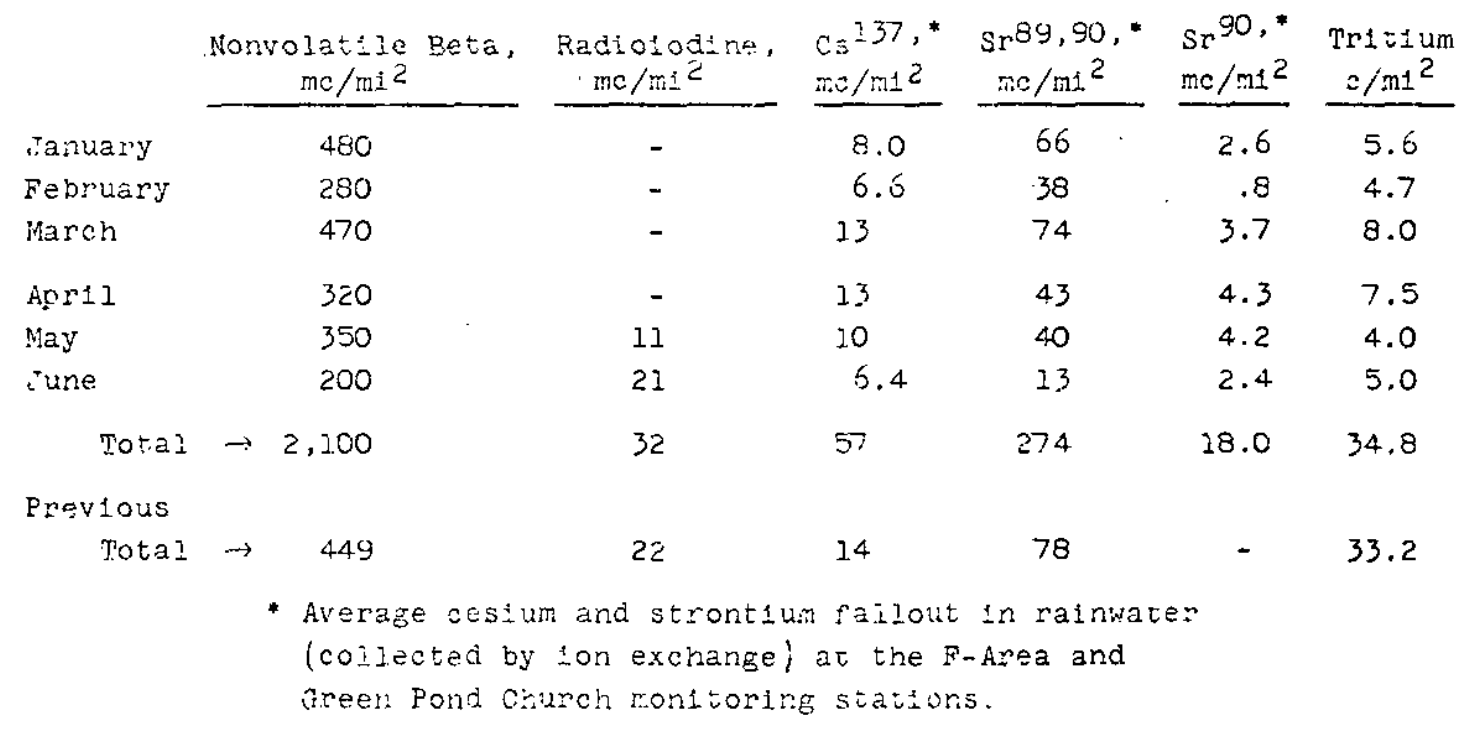




\section{Vegetation}

Concentrations ô radioactive materials in vegetation samples, collected from locations shown in figures 2 and 3 , are the result of fallout from the 1961 and 1962 nuclear tests. No influence due to Plant discharges of rasicactivity was apperent. The everage increase of nonvclatile beta emitters from 57 to $368 \mathrm{\mu \mu c} / \mathrm{g}$ was consistent with increasea rainfall. Radioactive materials in vegetation are summarized in Appendix B, table 4.

Milk

Milk samples were collected monthly from farms at Talatha, Snelling, and Pleasant. Mount, and weekly from dairies at Aiken, North Augusta, Barnwell, Williston, Waynesboro, and Allendale. I-131 was detected in dairy milk in May and June as a result of U. S. nuclear tests. Maximum I-131 concentrations in farm and dairy milk were $52 \mathrm{kHC} / \mathrm{l}$; and $4.3 \mathrm{\mu H} \mathrm{c} / \mathrm{l}$, respectively. (See Appendix B, table 5.) The calculated radiation dose to the thyroid of a child f'rom local milk during the 6-month period (average of all samples) was 28 mrem from iarm milk and 17 mrem from dairy milk. The adult thyroid dose, assuming the same 1 liter/day consumption rate, was onetenth the dose for a child.

\section{Plant Drinking Water}

Samples of drinking water were collected monthly from operating areas and quarterly from other Plant domestic water systems. Results of analyses are summarized in Appendix B, table 6 . Nonvolatile beta emitters in drinking water samples collected in $I$, $K$, and $C$ Areas (maximum of $37 \mathrm{\mu l} / \mathrm{l}$ ) were attributed to fallout from nuclear tests. Domestic water for these Areas comes from the river. Barxicade 2 drinking water had a maximum of $37 \mu \mu \mathrm{c} / \ell$ alpha and $69 \mathrm{\mu l} / \mathrm{c}$ nonvolatile beta activity which was natural radioactivity ( $\mathrm{Ra}-226)$ in the water. Drinking water samples contained no detectable tritium. 


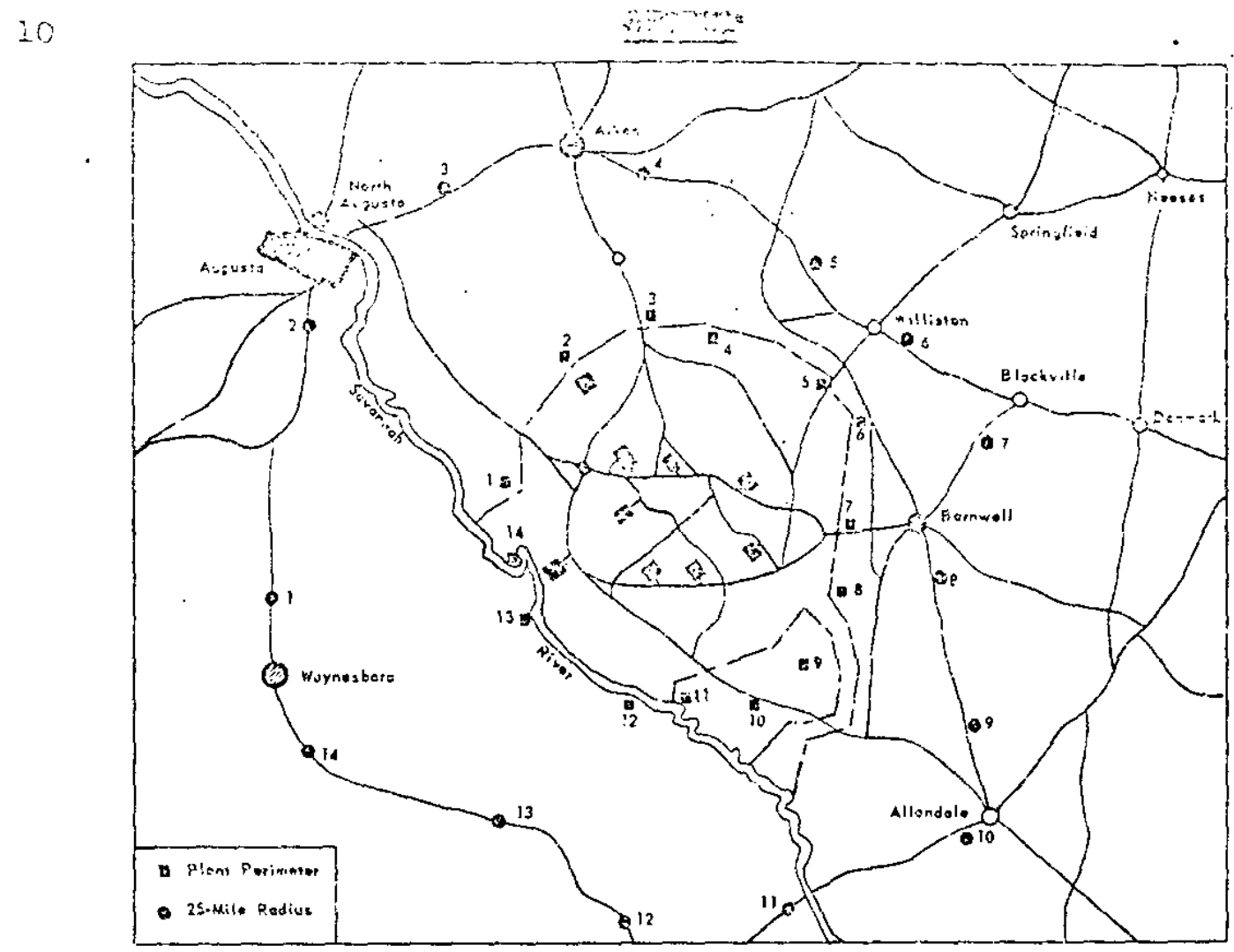

FIGURE 2: VEGETATION SAMPLE LOCATIONIS

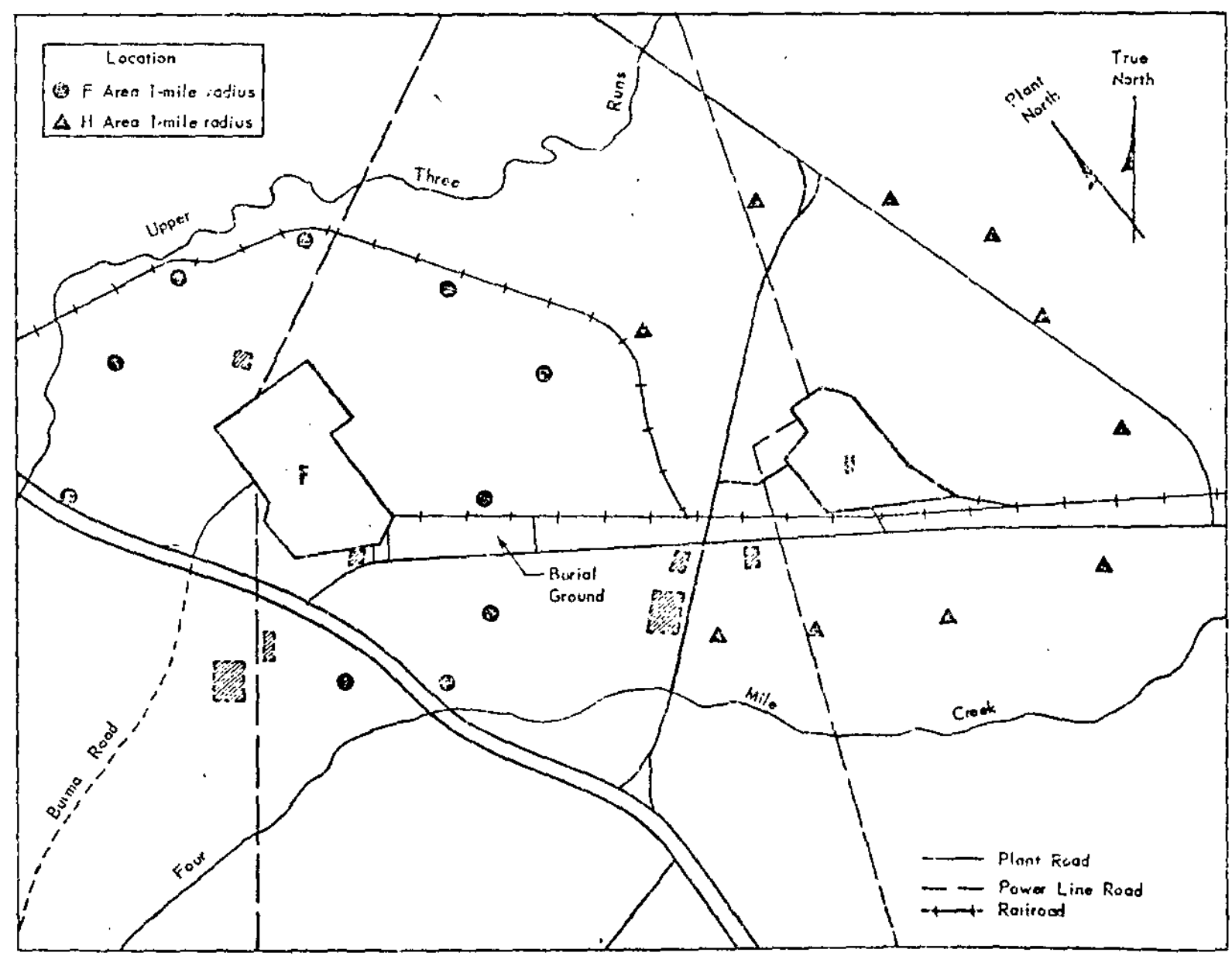

FIGURE 3. VEGETATION SAMPLE LOCATIONS IN F ANO H AREAS 
Piblic Water Suppliss

Semples of public irinking water, eollected monthiy from the 14 tows arown in figure 1, contained no letectable tritium activity. Analytical rosults are sumnarizea in Aprenaix B, table 7.

\section{Streams and the Savannah River}

Radicactive releases irom inaiviaual Plant, areas to effluent streams during the period are compared to those for the previous period in the following table. Individual radionuclide releeses from the Reactor Areas are presented in Appendix A, taile 2.

Radioactive Rejoases to Engluent Stregms

\begin{tabular}{|c|c|c|c|c|c|c|c|c|}
\hline \multirow[b]{3}{*}{ Area } & Aipha, & $m c^{2 *}$ & Nonvolani & je zera: & $8 a d=0 ; 0$ & dins, & 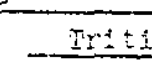 & $u m, c$ \\
\hline & & Prev & & Erev & & Prov & & Pnev \\
\hline & Iota 1 & To됴 & Total & Total & Dotai & Iotai & Iotal & Total \\
\hline $\bar{F}$ & 1.8 & 3.3 & 0.6 & 1.7 & - & - & 4 & 5 \\
\hline ii & 4.7 & 5.5 & 0.2 & 0.2 & - & - & 600 & $=3.300$ \\
\hline$R^{*}$ & - & - & 78.3 & 35.9 & 2.9 & 7.5 & 4,500 & 6,900 \\
\hline$P *$ & - & - & 201.8 & 14.4 & 74.7 & 0.4 & +.800 & 4,300 \\
\hline$L^{*}$ & - & - & $6: .7$ & 17.8 & 0.6 & 0.5 & 3,400 & 3,600 \\
\hline$K^{*}$ & - & - & 133.8 & 20.8 & 2.0 & 0.3 & 4,600 & 7,000 \\
\hline$c^{*}$ & - & - & 85.J & 13.8 & 2.0 & 0.8 & 7,600 & 5,300 \\
\hline 300 & $1: 0$ & 34 & - & - & - & - & - & - \\
\hline Total & $\rightarrow 216.5$ & 42.8 & 561.5 & 104.6 & 82.2 & 10.1 & 25,300 & 28,400 \\
\hline * & $\begin{array}{l}\text { Inciudes } \\
\text { Naturally } \\
\text { the Eeact } \\
\text { Reantor } \\
\text { curdes. }\end{array}$ & $\begin{array}{l}\text { orily } \\
\text { ocoui } \\
\text { or Are } \\
\text { jrea of } \\
\text { sinse }\end{array}$ & $\begin{array}{l}\text { eases iro } \\
\text { ig ipha } \\
\text { in } 2001 \\
\text { ients du } \\
\text { s antiy }\end{array}$ & $\begin{array}{l}\text { disassemk } \\
\text { itters in } \\
g \text { wats } \\
\text { ng the pey }\end{array}$ & $\begin{array}{l}\text { casin } \\
\text { !nnah } \\
\text { o rosal } \\
\text { d wase }\end{array}$ & $\begin{array}{l}\text { velrs. } \\
\text { nzer wa } \\
\text { alpha d } \\
\text { stimated } \\
\text { from Pi }\end{array}$ & $\begin{array}{l}\text { er pass } \\
\text { scrarged } \\
\text { o be } 40 \\
\text { it opera }\end{array}$ & $\begin{array}{l}\text { through } \\
\text { by the } \\
\text { nitizis } \\
\text { tons. }\end{array}$ \\
\hline
\end{tabular}

The principal source of radioactivity released from the Reactor Areas was disassembly basin water, purged at a rate of 1000 to 2000 gpm: Since its recognition in Octooer 1961, sulfur-35 ras been rhe

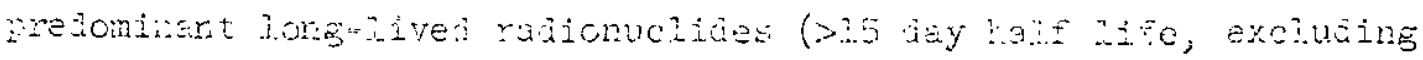
tritium) released in disassembly basin water. Sulfur-35 releases (approximately 262 curies) exceeded trose of $\mathrm{Cr}-5 \mathrm{l}$ (the major iongiived component previcusiy observed) by a factor of 2.6. Of the 
total bete activity (excludirg tritium) releesed from all Reacion Areas, approximately lo\% was due to radioisctopes heving alt lives greater than 15 àys.

The rupture of Mark V-B experimental fuel slugs (a total of 7 in the Raw Materials Area diring autoclave pressure test on May lc and 11) released an estimated $90 \mathrm{Lb}$ of uranium to a setting sump in the 300 Area. Tre release was equivaient to the total uranium released to Tims Branch for the previous 6 months. No increased alpha activity was observed in subsequent 300 Area effluent samples. It is possible that the uranium oxide remained in the simp.

Rajioactivity is measured in weekly water samples coliected continuousiy at the 18 stream locations and 7 river locations shown in figure 4. River mud samples, collected monthly at the 5 Plant perimeter locations and weekly from iocations 10 and 11 , were analyzed for TBP extractable alpra. Radioactivity of these samples is summarized in Apperaix B, tables 8 through 10. Radivactive materials in transport at the Road A intersection of each reactor effiluent stream are shown in the pollowing table. Data for river water at the control location and 10 miles downstream from the Plant are also shown.

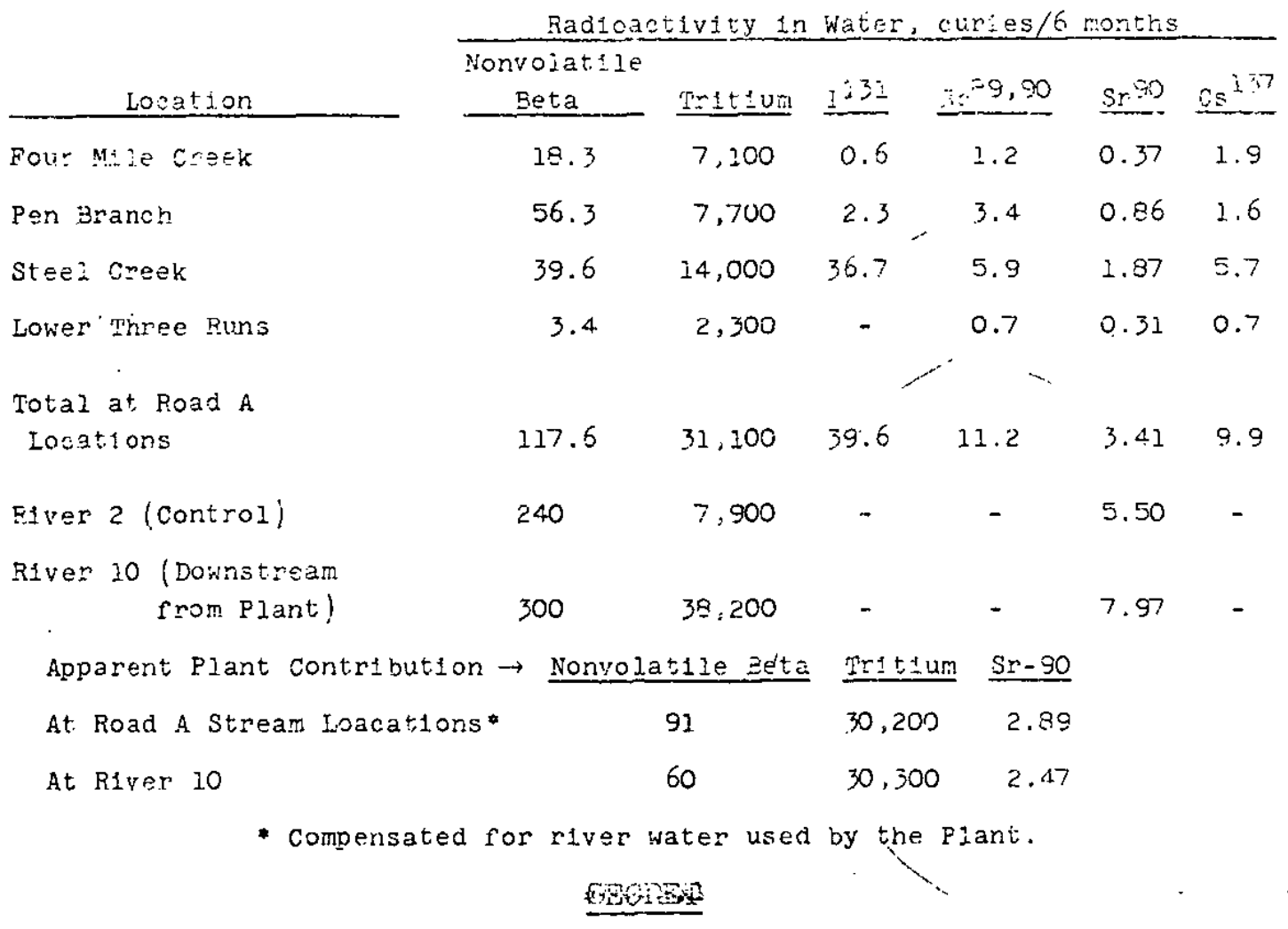




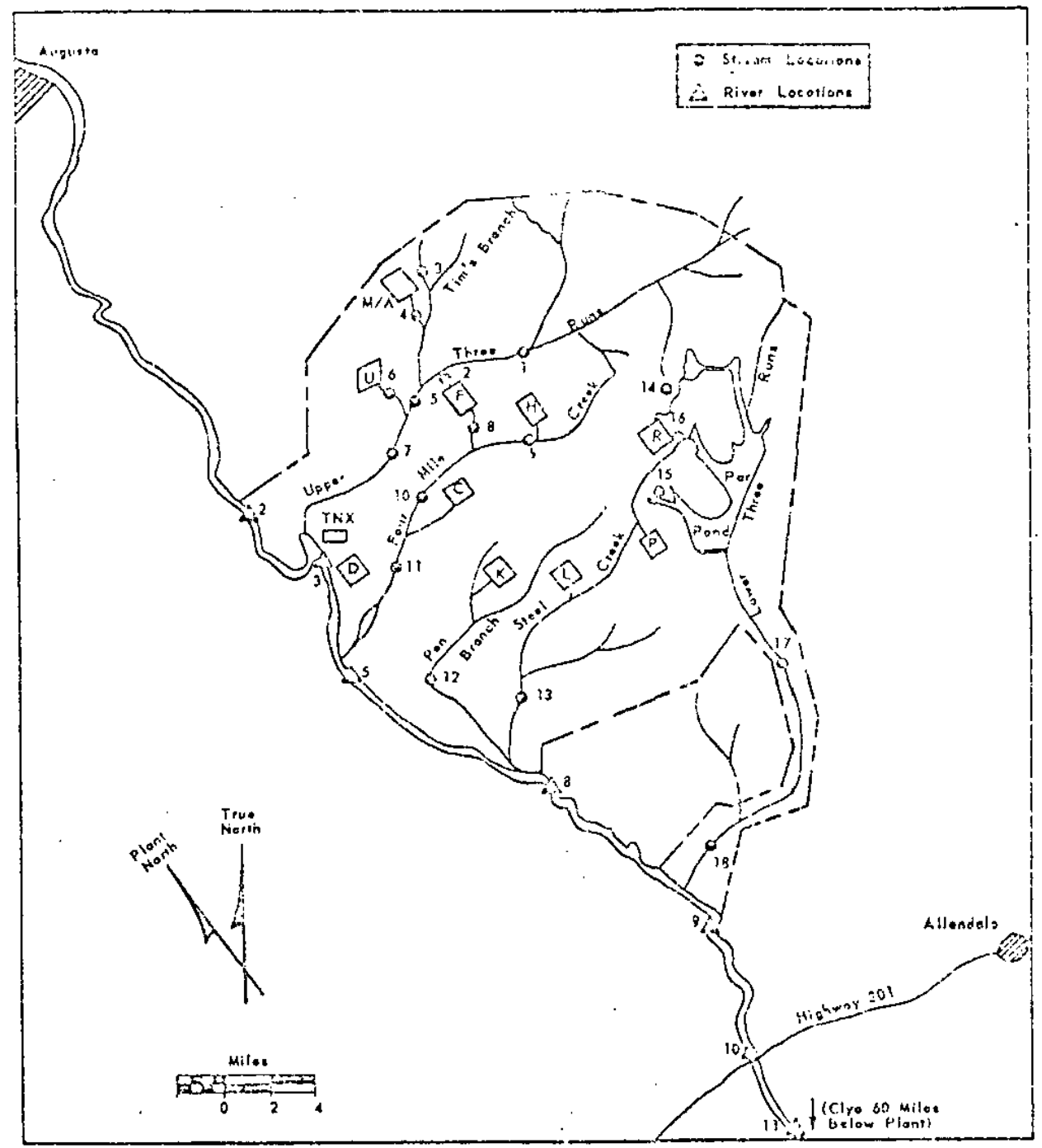

FIGURE 4. STREAM AND RIVER SAMPLE POINTS 
loxinm concontretions of both nowrolatile beta and tritium in

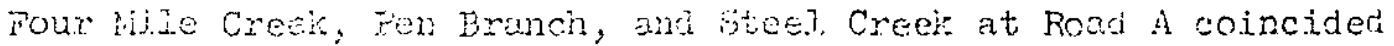
with fuel elenent diachare orerators. Comparatively high levels of robioiodine reve obsemed in steel Creek as a result of the ditechurge of a talted

ruel element durirg $P: 13-A$ outage.

While the towl releases (excluding tritium) from P Area during this outage were high (202.7 curies of wich 47.9 were radicnucilides having half lives greater than 15 days), relatively small concentrations of dajocctivity other tim I-I3I were observed in Steel Creek. Nonvolatile beta analyses of Steel Creek samples at Road A accounted for only 5\% of the veir releases (excluding $I-131$ and $5-35$ ). When purea weix releases were high, no cooline water was discharged to Steel Creel. The nonvolatile beta activity at Road A was higher after cooling. water was returned to steel Creek than it was during the period of highest weir activity.

The maximum alpia $(1900 \mu \mu \mathrm{c} / \ell)$ and nonvolatile beta $(4400 \mu \mathrm{k} / \mathrm{l})$ concentrations in the Fonrea stom sewer elfluent were attributed to the $s$-Line facjlity; however, the exact origin was not, identified.

Faliout contamination from nucleser tests was evident ju river water througiout the period. The concentration of nonvolatile detci activity $(93 \mu \mathrm{c} / \mathrm{l})$ in the river at the upstream control jucation during the week ending March 13 was the bjentest observed since July through December 1957 (140 unc/l maximum). Gamma spectroanalysis of 34 gallons of river water collected at the control location revealed photopeaks identified as $\mathrm{Ce}^{241,344}$, Rul03,106, and $\mathrm{Zr}-\mathrm{Nb} \mathrm{b}^{\mathrm{S}}$.

\section{Seepage Basins}

Radioactivity discharged to earthen seepage basins are compared to the previous 6month discharges in the following taule. Isotopic distribution of the nonvolatile beta discharged to the $F$ and $\mathrm{H}-$ Area basins is shown in Appendix $A_{2}$ table 3 . 
Fodionctivity Discharged to Depare lasins

\begin{tabular}{|c|c|c|c|c|c|c|c|c|}
\hline \multirow{3}{*}{ Arca } & \multicolumn{2}{|c|}{ Apha, re } & \multicolumn{2}{|c|}{ Hoivolatile Jota, } & \multicolumn{2}{|c|}{ Rajiojodine, } & \multicolumn{2}{|c|}{ Triclin, $c$} \\
\hline & isc & Frev & & Erev & & PreV & & Prev \\
\hline & JcEal & Tetas & Iotal & Tota1 & 20ial & & Iotal & \\
\hline $\mathrm{F}$ & 521 & 68 & 120.2 & 29.5 & 3.4 & 0.3 & & \\
\hline $\mathrm{H}$ & 237 & 144 & 15.2 & 29.5 & 0.1 & 0.2 & & \\
\hline B & - & - & $=$ & & $\cdot$ & & 7 & - \\
\hline & & & & & & & & \\
\hline$P$ & - & - & 7.6 & 14.5 & - & - & 84 & 13 \\
\hline $\mathrm{I}^{*}$ & - & - & 0.03 & . & - & - & 12 & 32 \\
\hline $\mathrm{K}$ & - & - & - & - & - & - & - & - \\
\hline$c$ & - & - & 2.8 & 3.2 & - & - & 746 & 2,134 \\
\hline $3 / 100$ & 20 & 19 & 0.04 & .04 & $\therefore$ & - & : & - \\
\hline Motai- & 778 & 231 & 136.27 & 76.74 & 3.5 & 0.5 & 26,601 & 33,066 \\
\hline
\end{tabular}

- 1795 curies of tritlum and 8.5 clirles of nonvolat1le beta activity were released to the 011 and chemcal disposal plt in L Area. Esseritially all of thls oame from the c-Area heat exchanger decontamination fac1lity.

Rut 103,200 and $\mathrm{CS}^{237}$ vere the major gamma emitting radionucliues released to the F-Area seepage Dasin and were associated wi.th waste from Building $211-F$ and increased $242-F$ evaporator operations, respectively. The maxinum relesse oi nonvolatile beta activity (22.6 curies during two weeks in June) coincided with the diversion of water from the $281-5 F$ delaying basin to the seepage basin followine the contamination of the cooling water systems in F Area on June 14. This activity (primarily $R u^{103}, 100$ ) was attributed to repairs to the $9.3 \mathrm{E}$ high activity waste evaporator in Building $221-F$.

A computer program was used to determine the amount of tritium introduced daily into the F-Area dissolvers during the period. The calculation was based on a fission-to-tritiun ratio established by SRL, and all uranium charged to the Separations Process from January 7 through June 30, 1962, with the exception of a small number of off-Plant elements for which no reactor ex- 


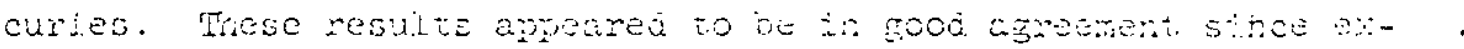

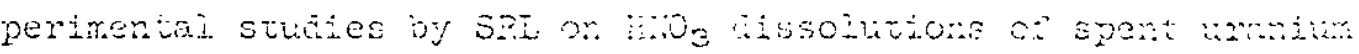

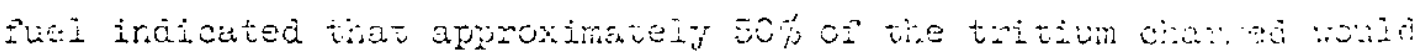

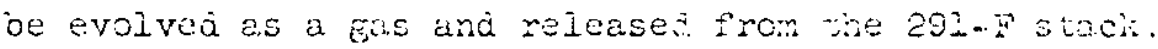

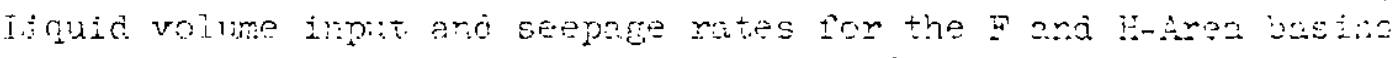
are shown in the followine tabie.

10

\begin{tabular}{lrr} 
Liters/Fay & FArea & ri Area \\
\cline { 3 - 3 } Waste Irput & $10.1 \times 10^{5}$ & $3.0 \times 10^{5}$ \\
Rain Input & $0.8 \times 10^{5}$ & $0.7 \times 10^{5}$ \\
Seepare Pate & $3.0 \times 10^{5}$ & $3.9 \times 10^{5}$
\end{tabular}

The racioactivity in Separations, 700 , and Tix Areas seepare basins is shown ir Appendix $B$, tajle 1 i.

The major sources of radioactivity released to the Reactor Areia seepage bainins were the hanajing of Cralk fiver reactor components in $P$ Area and the deconternination of heat excrangers in $C$ Area.

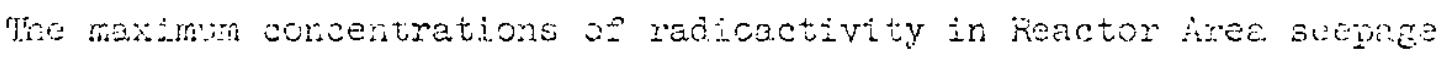
basin water, ooserved in C Area basin I, vare as fojlows: aipha

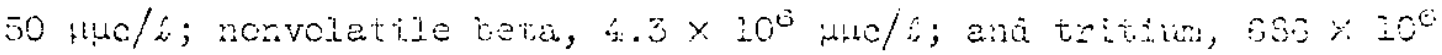
ipic/is.

\section{Groind Water}

Ground water was monitored by analysis of sampies collected from welis surrcunding $F, H$, and R-Area seepage basins (firrues 5 and $C$ ), wells near $F$ and $H$ Areas ( $Z$ and $Z W$ Weils; Fifires 7 ard $B$ ); aid wells at the burial ground ( $r$ igure 9 ). The maximuin ronvolaticio beta concentration in sampies coilected from the R-Area seepace basin wells was $140 \mu \mathrm{c} / \ell$ in well $\mathrm{Cl}$, approximately $2300^{\prime}$ west of. back-filled basins 2 and 3 . Analytical results of $Z$, ZW: and $F$ and $H$-Area seepage basin well weter are shown in Appenoix B̈; tables 12 and 13 . 


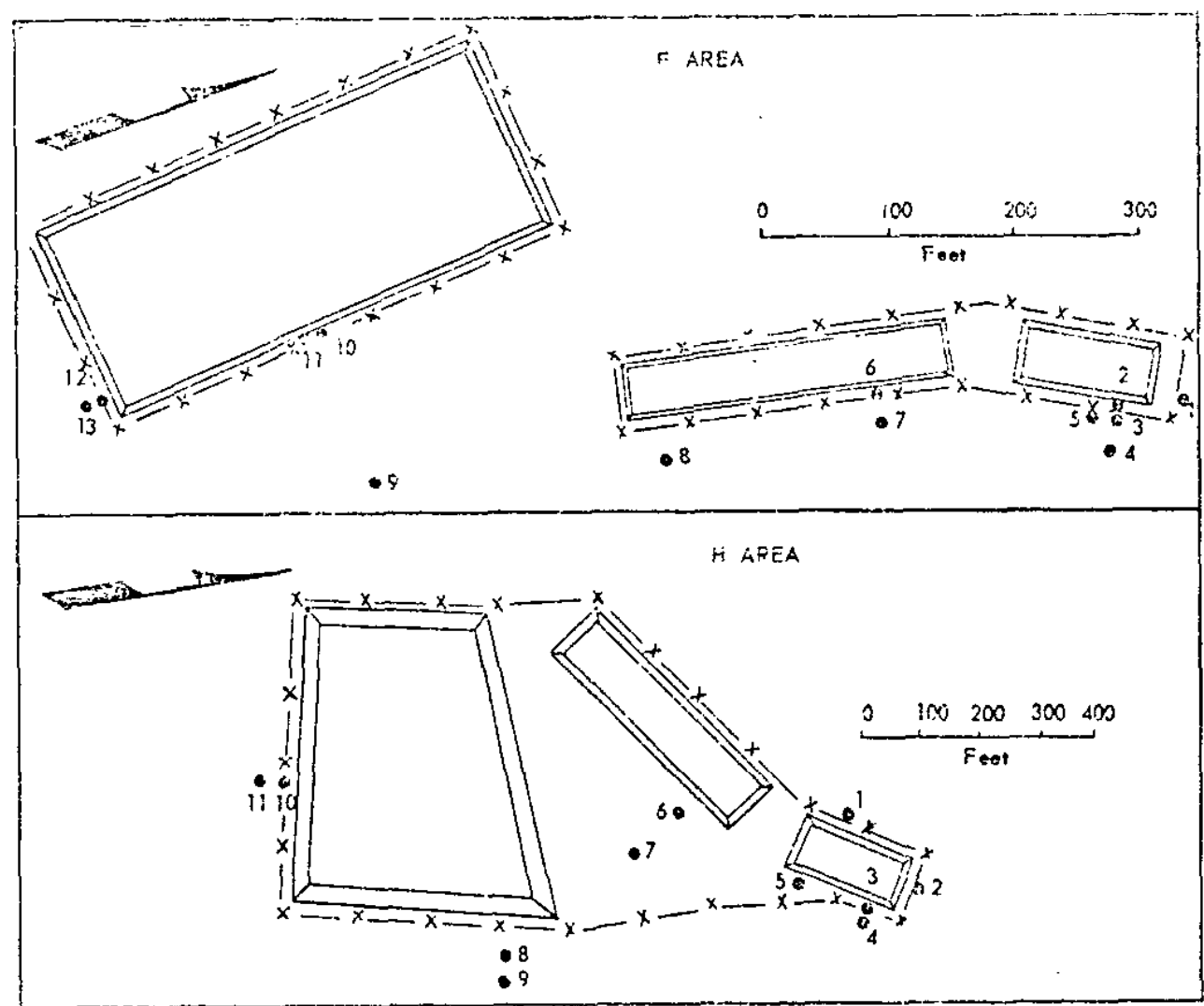

FIGURE 5. SEEPAGE.BASIN MONITORING WELLS IN F AND H AREAS

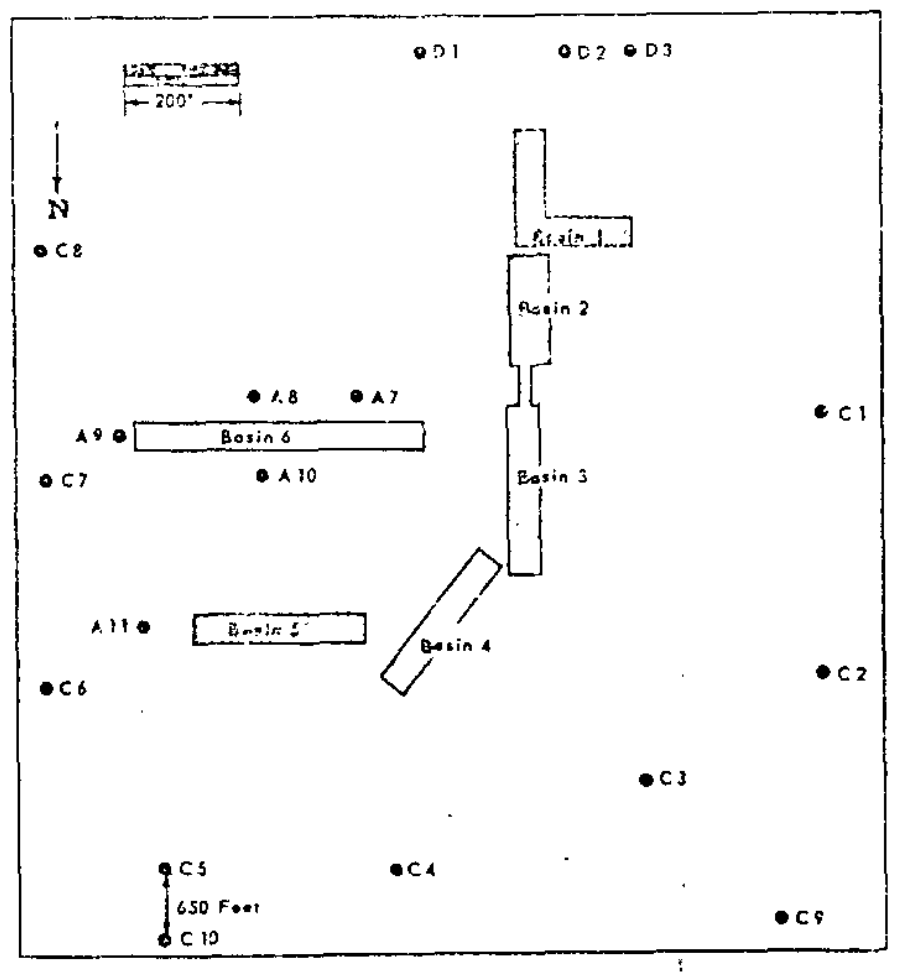

FIGURE 6. R-AREA SEEPAGE BASINS AND MCMITORING WELLS

$\square$ Backfiliod Busint 


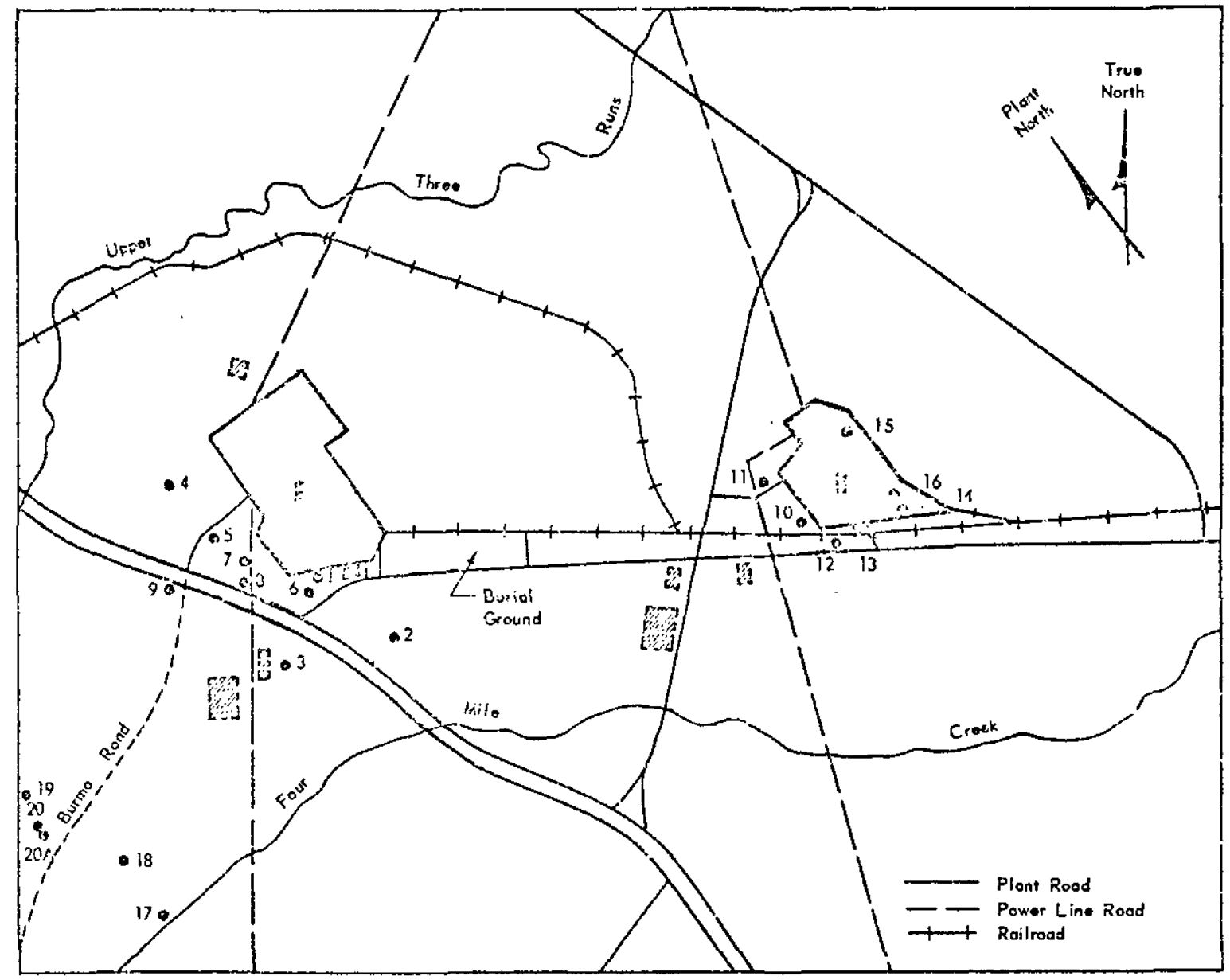

FIGURE 7. Z-WELL LOCATIONS 


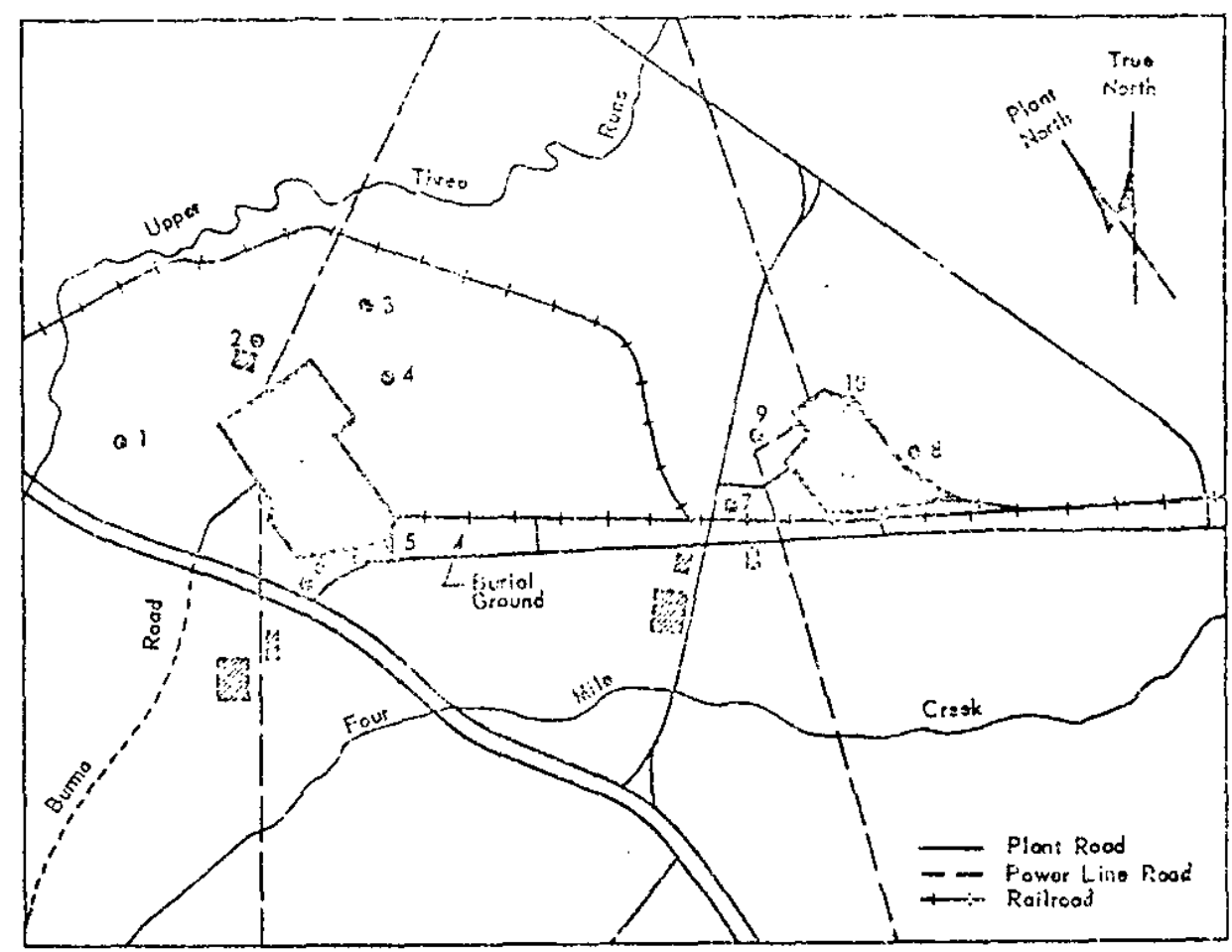

FIGURE E. ZU MELLS, F AID H AREAS

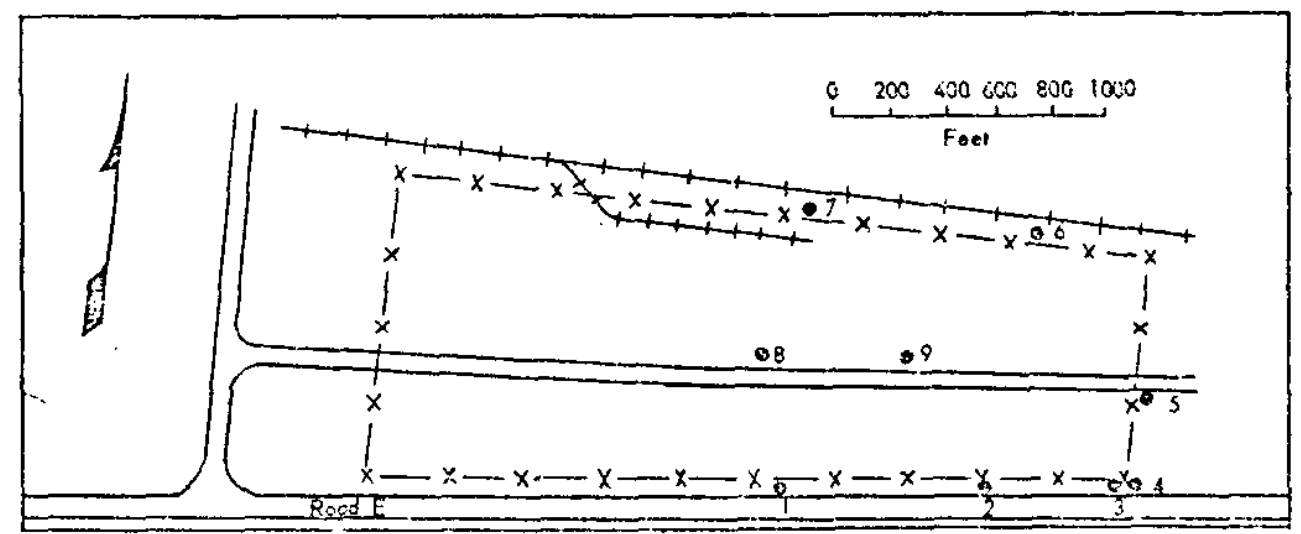

FIGURE 9. BUR!AL GROUND KELLS 


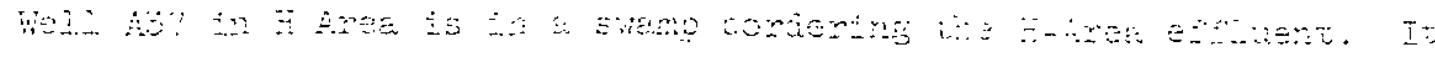

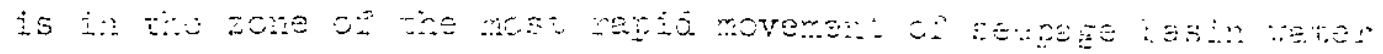

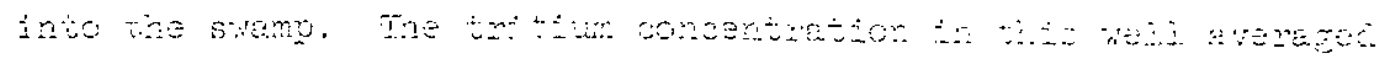

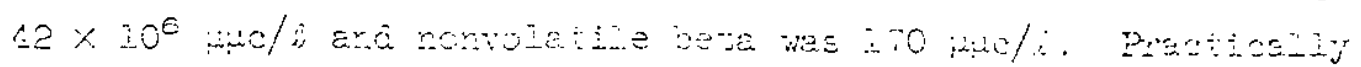

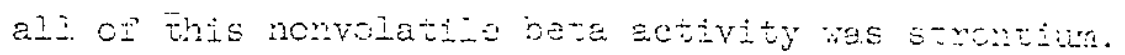

\section{1-H Tank Farm}

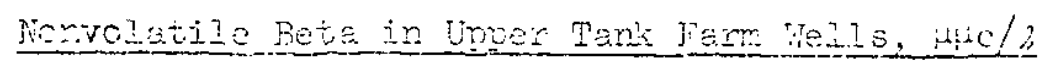

\begin{tabular}{|c|c|c|c|c|c|c|}
\hline & $\begin{array}{l}\text { HFIs } \\
\text { WeIIS }\end{array}$ & $\mathrm{IPI}$ & EPS & $5 P$ & Tw3 & 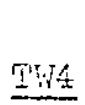 \\
\hline laximum & 200 & 430 & 70 & 220 & 160,000 & 730 \\
\hline Average & 54 & 300 & 52 & 140 & $\hat{\sigma} \varepsilon, 000$ & \\
\hline Previous Average & 30 & $3 \pm 0$ & 1.1 .0 & 220 & 200,000 & 50 \\
\hline
\end{tabular}

The 12 HFM wells (shom in figure 20 ) are installed at unequal intonvals at a distance of 15 feet frum the cuter edge of the Upper Iank Farm concrete pad, extenoing 10 feet belor the pad. The HP wells were the intial wells fhich vere ariller rive teet avay from the tank 1.6 encasenent (cow to the concrete pai) following the loss of radioactive meteriels from the annulus of this 16 in september 1960. Wells WHS and Iris vere installed ciuring construction of the 241.-1 Upper Tank Farm. The comparatively ing concentrations in Thb are due to the puinpire of the soil sininikege system from Riser 5 (TA 5-6). This pumping caused ground water movement from the vicinity of tank 16 to the center of the system, the location of boti Riser 5 and. TW3. Negligible concentrations of nonvolatile beta activity were observed in water collected weekly from a preexisting test well. in the center of the Lower Tank Farm.

\section{Biological Specimers}

TEFRESTRTAL

The reacton effluent syeteme (imnluding Par Pord) and etmospreric fallout from nuciear tesis were the primary sources of rauioactivity in terrestrial mina.s. Slightiy higier nonvolatile beta concentrations in the four species collected during this period were 


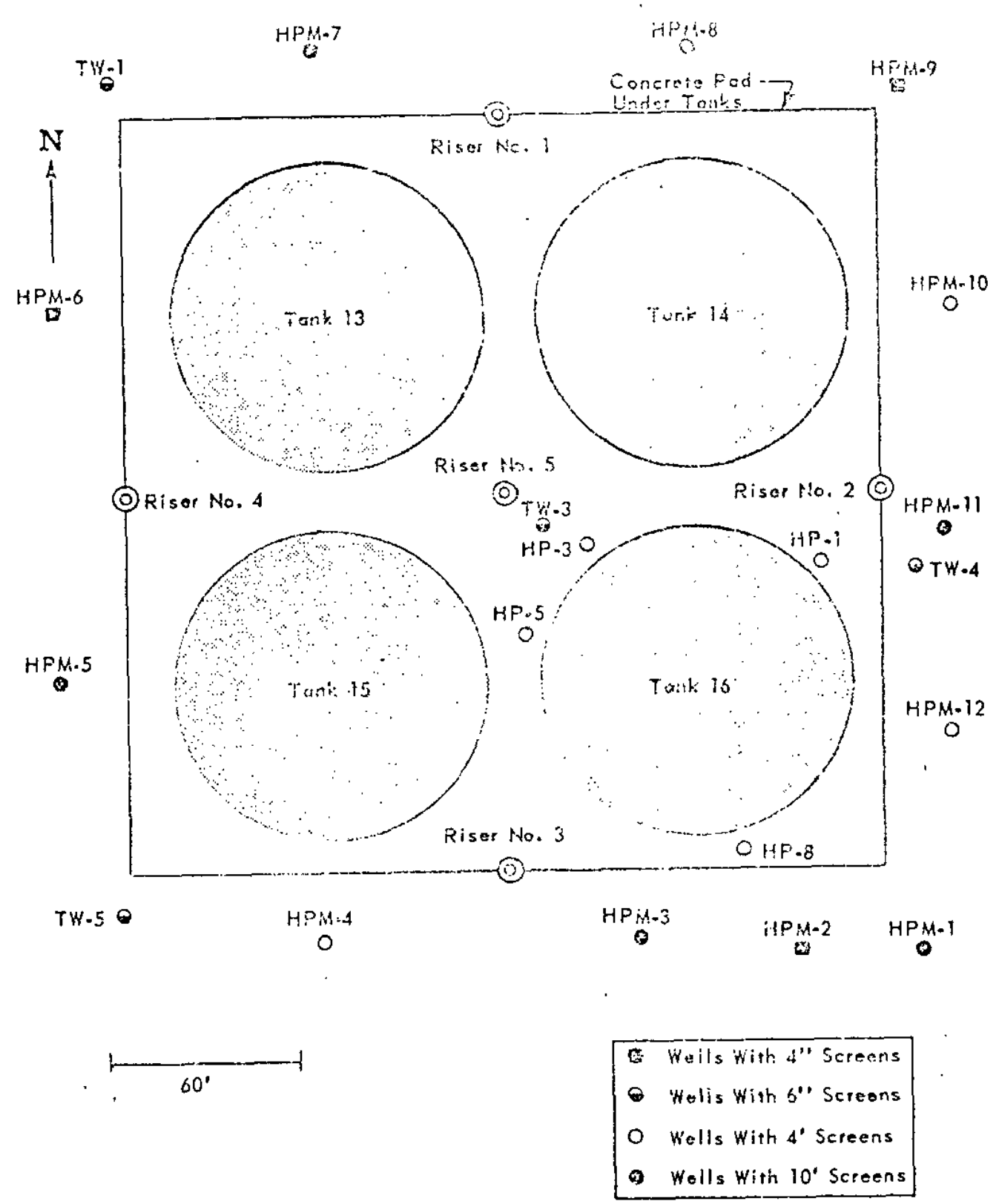

FIGURE N. UPPER TANK FARM WELI.S, 24IH 
attrikuted primarily to fellout. Pariostrontium ( $\mathrm{Sr} \theta 3$, 80 ) was the primary radionuclide in the bones. Low level concentrations of radiocesium ( $\mathrm{Cs}^{13 T}$ ) were present in the fleshy tissues of scme specimens. Comparative nonvolatile beta concentrations are presented in the following table.

Nonvolatile Beta in Terrestrial Animals, $\mu$ inc/g (wet weight)

\begin{tabular}{|c|c|c|c|c|c|c|c|}
\hline \multirow[b]{2}{*}{ Species } & \multirow{2}{*}{$\begin{array}{l}\text { No. of } \\
\text { Semples }\end{array}$} & \multicolumn{3}{|c|}{ Bone } & \multicolumn{3}{|c|}{ Flesi } \\
\hline & & $\operatorname{Max}$ & $\mathrm{Avg}$ & Prev Avg & Max & Avg & Prev Avg \\
\hline Rabbit & 3 & 75 & 45 & 20 & 15 & 8 & 4 \\
\hline Bobcat & 2 & 7 & 6 & 7 & 16 & 12 & 7 \\
\hline Raccoon & 1 & - & 20 & 10 & - & 6 & 9 \\
\hline Deer & 1 & - & 13 & 7 & - & 6 & 4 \\
\hline
\end{tabular}

The concentrations of I-13I in the thyroid slands of these terrestrial animals averaged $50 \mu \mathrm{\mu c} / \delta$ (wet weight). Concentrations in the herbivore thyroids were slightly higher than those in the carnivore thyroids.

AVIAN

Forty-three migratory wateriowl (2 teal, 7 mallard, and 34 ringneck ducks) and 2 coots were collected from Par Pond during the first three months of the period. The coots had the highest average concentrations of nonvolatile beta. They feed primarily on animal matter and inhabit Par Pond longer than the other waterfowl. The predominant isotopes in the bones were radiozinc $\left(2 \mathrm{n}^{\epsilon} \overline{5}\right)$, radiostrontium $\left(\mathrm{Sr}^{89}, 50\right)$, and radiocesium ( $\left.\mathrm{Cs}^{134,137}\right)$. Radiozinc and radiocesium were the primary isotopes in fleshy tissues. Except for decreased concentrations in bones and fleshy tissues of teals, the ronvolatile beta in these specimens approximated that found during the first 6 months of 1961. 


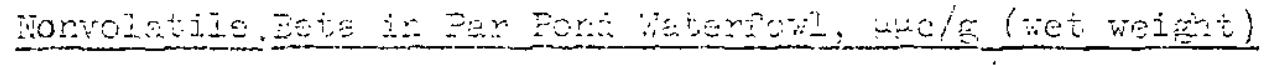

\begin{tabular}{|c|c|c|c|c|c|c|c|}
\hline \multirow[b]{2}{*}{ Species } & \multirow[b]{2}{*}{ Serntes } & \multicolumn{3}{|c|}{ Borde } & \multicolumn{3}{|c|}{ Flesin } \\
\hline & & iney & 68 & $2 x 6$ & $\sqrt{5 x}$ & $\Delta S$ & $A v v$ AvE \\
\hline Teal & 2 & 10 & 20 & 25 & 0 & 6 & 20 \\
\hline Maliara & 7 & 12 & 6 & 5 & 3 & 5 & 10 \\
\hline
\end{tabular}

Ringnecis 3:

$\operatorname{coot}$

$50 \quad i 3 \quad 20$

$23 \quad 28 \quad 30 \%$

2.1 9

5

* Aversge of 2 specimens collectec in December 1961.

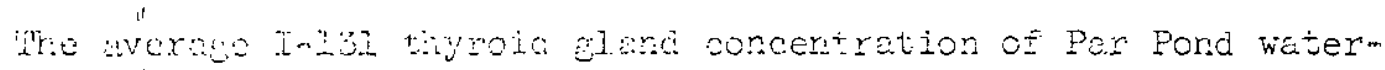
fowl collectez in January was $125 \mu$ llo/g (wet weight). The maximun concertration, found in the tinyroid gland of a teal, was $645 \mathrm{H \mu c} / \mathrm{g}$. Radioicdine concentrations in specimens collected in February and March were less then $70 \mu \mu \mathrm{c} / g$ (sensitivity of analysis).

The bones and fleshy tissues of a goose collected from 281-3F basin in June contained detectable concentrations of $\mathrm{Ce}^{\mathrm{i} 4 \mathrm{I}}, \mathrm{144}$ (bone 120 $\mu \mu \mathrm{c} / \mathrm{g}$; fllesh $20 \mathrm{mic} / \mathrm{g}$, wet weight) and $\mathrm{Cs} i 37$ (bone $30 \mathrm{\mu Hc} / \mathrm{g}$, rlesin $15 \mu \mu \mathrm{c} / \mathrm{g})$. S se, so concentration in fleshy tissues vas less than the sensitivity of analysis. The concentration in the bones was $8 \mu \mu c / g$ (vet weight).

\section{AQUATIC}

A total of 638 aquatic samples (450 fish, 175 aljee samples, and 4 clams) were collected from Plant effluents and the Savannan Rirer. Samples from effluents were radioanalyzed for uptake of Plantcontributed radioactivity. River samples weie analyzed to determ mine radionalide concentrations in aquatic specimens acressible to the pubiic.

Reactor Effluent Svecimens. Fish end algue samples were routinely coliected irom the R-Area effluent system (Par Pond and Lower Triee Runs) and from Steel Creek to moritor radioactivity uptake. Sarijes collected from Lower Three kuns at 1, 6, and 14miles bolovi Por Pond dam helped determine effects of dilution and streamed remoral ot radioactivity on the uptake of rajionucidies by fish and aizae. 
Steel Creek fish ere exposed to weste from tro pector lress and represent the maximun concentrations encountersi.

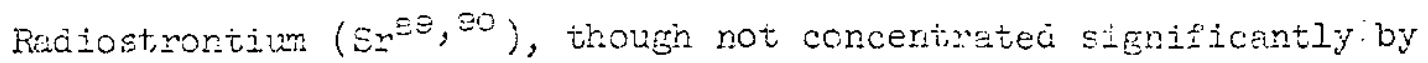
the fleshy tissies, has the primary beta emitter iuentified in the

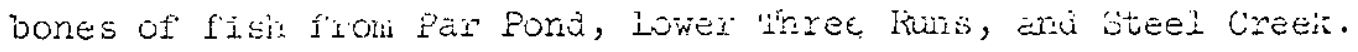
Radiozine $\left(\mathrm{Zn}^{3}\right)$ and radiocesium $\left(\mathrm{Cs}^{234}, 137\right.$ ) were the precominant gamme emitters in the bones and rleshy tissues, respectively. Howevex, the cominance and magnituce of spectic nuclides in fish tissues variea signiricantly between sample locations as shown in the following teble.

Radionuclides in Effluent Fisin, $\mu$ ic/s (wet weigit)

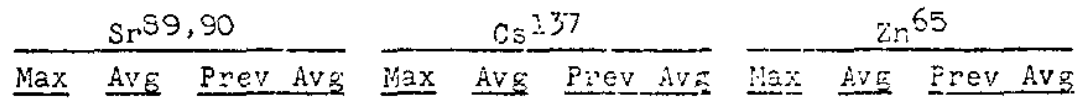

Par Pond

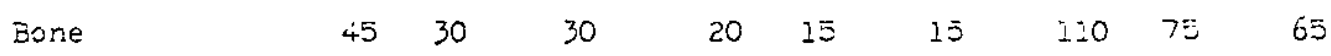

Flest:

$* \quad * \quad 45 \quad 35 \quad 30 \quad 25 \quad 20 \quad 15$

Lower three Runs Bone

Flesh

$\begin{array}{rrrrr}20 & 35 & 20 & 25 & 10 \\ * & * & * & 45 & 25\end{array}$

Stee? Creek Enne ồ

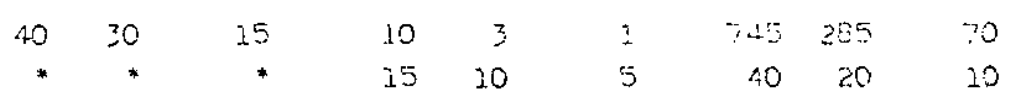

* Less than sensitivity of anaiysis.

Algue is routinely monitored because it hes a high sorption for radioactivity and is an important link in the food chain of fith and man. Since algae concentrate radioactivity from the voter by factors up to $10^{4}$, they are good qualitative indicaton's of the radioruclide content of water. Large algae samples (5 to 30 grans dry weight) vere collected weekly in May and June for gamme spectrometry and radiostrontium analyses. Results are shown in the following table. 
Redionvelices in $=07$.

\begin{tabular}{|c|c|c|c|c|c|c|}
\hline \multirow[b]{2}{*}{ Isotope } & \multicolumn{2}{|c|}{ Par Pone } & \multicolumn{2}{|c|}{ Icrow a } & \multicolumn{2}{|c|}{$\operatorname{sen} \operatorname{cras}$} \\
\hline & $r_{1}=x$ & $\because E$ & 6 & 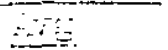 & 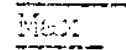 & $\therefore 9$ \\
\hline$C e^{2 A i}, 24 A$ & 840 & $5 ! 3$ & I. & 75 & 2440 & 1050 \\
\hline $\mathrm{C}_{2}=\mathrm{i}$ & 800 & 360 & 65 & 15 & 5350 & 1720 \\
\hline$F u+c s, \pm C$ & 500 & 295 & 135 & 500. & 23.50 & 520 \\
\hline $\cos ^{2.37}$ & 330 & 230 & 20 & 5 & 670 & 255 \\
\hline $2 \mathrm{r}-\mathrm{THD}^{65}$ & 435 & $240^{\circ}$ & 45 & 20 & 680 & 280 \\
\hline $\operatorname{lng}^{5} i_{t}$ & 270 & 150 & * & $*$ & 100 & 5 \\
\hline $\ln 65$ & 1300 & 730 & * & * & 1050 & 41.0 \\
\hline $\mathrm{Fe}^{5 \sigma} / \mathrm{Co}^{6 \mathrm{C}}$ & 515 & 200 & * & $*$ & 230 & 1.35 \\
\hline$B a-I_{2} a^{140}$ & 285 & 70 & * & * & 1550 & 655 \\
\hline $\mathrm{Sr}^{89}, 50^{* *}$ & 90 & 55 & 20 & 15 & 80 & . \\
\hline
\end{tabular}

* Less than sensitivity of analysis.

* Determined by radiochernical analysis.

Savannah River Srecimens. Nuclear tests fallout caused nonvolatile beta concentrations in river algae collectea above and below the plant site to be twice as hish as during the previous period.

Nonvolatile Beta in River Algze, witc/s (avy weight)

\begin{tabular}{|c|c|c|c|c|}
\hline River Location & Samples & $\operatorname{Max}$ & $\dot{A V g}$ & Prev Avg \\
\hline 3 Miles Above Plant & 17 & 205 & 100 & 40 \\
\hline Steel Creek & 19 & 1020 & 105 & 450 \\
\hline 10 Miles Belov plant & 19 & 315 & 13 & 65 \\
\hline
\end{tabular}

The uptake of radioactivity by river fish collected above, adjacent to, and below the Plant site was generally confined to low level concentrations of radiostrontium $\left(E n^{3},{ }^{\circ}\right)$ in the bones. There was no siznif'icant concentration ot radicstruntiun in f'lesiy tissues. An occasional fish contained trace concentrations of Cs-137 in the fleshy tissues.

Nonvolatile Beta in River Fish, Huc/g (vet weight)

\begin{tabular}{|c|c|c|c|c|c|c|c|}
\hline \multirow[b]{2}{*}{ Location } & \multirow[b]{2}{*}{ Sampies } & \multicolumn{3}{|c|}{ Bone } & \multicolumn{3}{|c|}{ F']esh } \\
\hline & & hex & $\Delta \mathrm{Vg}$ & Prev ivg & Iiax & EVE & PreV AVE \\
\hline A & 20 & 28 & 16 & 8 & 8 & 4 & 4 \\
\hline Creek & 23 & 72 & 20 & 20 & 10 & 6 & 6 \\
\hline Les Below Plant & 13 & 35 & 14 & 13 & 6 & 5 & 4 \\
\hline
\end{tabular}




\section{Chemical Quality Of Water}

\section{Savannahs River}

Water quality upstream (location 2) and dowrstream (location 10) from the Plant $i$ shorm in the folloring tebls. All data axcept those for dissolved oxygen and $B O D$ represent the average anslyses of water samples collected weekly. The dissolved oxygen and BOD values reflect the average of weekly determinations of oxygen at the time of collection. The data indicate that SRP operations have no effect on the chemical quality of the river.

Color, APHA

$\mathrm{pH}$

Methyl Orange, ppm $\mathrm{CaCO}_{3}$

Dissolved Oxyenen, ppm

Sulfide, ppris

Harciness, ppm $\mathrm{CaCO}_{3}$

Conductivity, umios

IDS, ppm

BOD, prm

Lignir, ppm

Total Iron, ppm Fe

Chloride, ppm $\mathrm{Cl}$

Nitrite, ppm $\mathrm{N}$

Nitrate, ppm $N$

Sulfate, $\mathrm{ppm} \mathrm{SO}_{4}$

Phosphate, ppm $\mathrm{PO}_{4}$

Surfactant,
Savannah Fiver Chemicai Quality of Water

\begin{tabular}{|c|c|c|c|c|c|}
\hline \multicolumn{3}{|c|}{ Upstreaim } & \multicolumn{3}{|c|}{ Downstream } \\
\hline $\operatorname{Max}$ & Min & Avg & $\operatorname{lax}$ & $M n$ & AvS \\
\hline 55 & 15 & 34 & 50 & 15 & 33 \\
\hline 7.4 & 6.8 & 7.1 & 8.0 & 6.8 & 7.1 \\
\hline 19 & 21 & 10 & 50 & 12 & 17 \\
\hline 12.4 & 7.7 & 9.6 & 11.2 & 6.7 & 9.1 \\
\hline$<0.2$ & $<0.2$ & $<0.2$ & $<0.2$ & $<0.2$ & $<0.2$ \\
\hline 17 & 10 & 13 & 16 & 9 & j.3 \\
\hline 55 & 35 & 47 & 55 & 40 & 4.7 \\
\hline 50 & 20 & 38 & 49 & 11 & 38 \\
\hline 1.6 & 0 & 0.7 & 1.7 & 0 & 0.5 \\
\hline 6.6 & 0.7 & 3.6 & 7.0 & $2 . \hat{z}$ & 3.8 \\
\hline 1.9 & 0.6 & 2.0 & 1.4 & 0.6 & 1.0 \\
\hline 4.2 & 0.8 & 2.6 & 4.8 & 1.1 & 2.3 \\
\hline 0.004 & 0.001 & 0.002 & 0.025 & 0.001 & 0.003 \\
\hline 0.08 & 0.02 & 0.04 & 0.09 & 0.02 & 0.04 \\
\hline 3.2 & $<2.0$ & $<2.0$ & 3.0 & $<2.0$ & $<2.0$ \\
\hline 29.4 & $<0.3$ & 4.8 & 23.5 & $<0.3$ & 5.2 \\
\hline 0.04 & $<0.02$ & $<0.02$ & 0.03 & $<0.02$ & $<0,02$ \\
\hline
\end{tabular}


Lower THree Runs.

Because Lower Throe Fur Stsion at Bopd A is pproximetely onem half mile cowstrem pum the eriluent os a rool scouring plent, a control locetion was established three miles upstrean from foad A. The cherical cuality oi the waten at these two locatinns is snown in the following belle. The date inaicate that the nill effluent had no significant effect on chemical guality of Lower Three Funs water. However, aquatic insect collections above and below the mill effluent continue to indicete a devreszed insect population downstrear from tine mill.

Color, APYA

$\mathrm{pH}$

Nethy Orange, $_{\text {pm }} \mathrm{CaCO}_{3}$

Dissoived oxyer, ppon

Sulfide, ppm $S$

Hasciness, Ppia $\mathrm{CaOS}_{3}$

Conductivity, finhos

TDS : ppm

BOD, ppm

Lisnin, ppm

Tot, 31 Iron, ppm Fr:

Chlorsde, ppm CI

Nitrite, ppin $N$

Nitrate, ppm in

Silfate, ppm So 4

Fhosphate: ppm $\mathrm{PO}_{4}$

Surfactant: ppm

Lower Tiree Rurs

Cremicaz Quaitiy of Hater

\begin{tabular}{|c|c|c|c|c|c|}
\hline \multicolumn{3}{|c|}{ Above Mill Eñivent } & \multicolumn{3}{|c|}{ Be 10w MLII Enfluent } \\
\hline $\operatorname{Max}$ & men & Avg & 릴 & Mn & $A \cup D_{0}$ \\
\hline 60 & 20 & 35 & 60 & 20 & 36 \\
\hline 7.7 & 7.0 & $7.2^{\circ}$ & 7.5 & 5.9 & 7.2 \\
\hline 31 & 15 & 24 & 33 & 12 & 24 \\
\hline 12.6 & 6.2 & 8.9 & 12.0 & 5.8 & 0.8 \\
\hline$<0.2$ & $<0.2$ & $<0.2$ & $<0.2$ & $<0.2$ & $<0.2$ \\
\hline 35 & 10 & $24^{2}$ & 49 & $=8$ & 27 \\
\hline 72 & 44 & 59 & $76^{\circ}$ & 43 & 61 \\
\hline 60 & 18 & 42 & 68 & 21 & 43 \\
\hline 1.3 & 0 & 0.6 & 1.2 & 0 & 0.5 \\
\hline 7.9 & 2.5 & 4.4 & 8.1 & 2.4 & 4.6 \\
\hline 3.0 & $0.2^{\circ}$ & 0.5 & 1.7 & 0.2 & 0.7 \\
\hline 2.6 & 0.5 & 1.5 & 3.0 & 0.5 & 1.6 \\
\hline 0.003 & 0.002 & 0.002 & 0.003 & 0.002 & 0.002 \\
\hline 0.05 & 0.02 & 0.03 & 0.04 & 0.02 & 0.03 \\
\hline$<2.0$ & $<2.0$ & $<2.0$ & 2.5 & $<0.0$ & $\therefore 2.0$ \\
\hline 16.4 & $<0.3$ & 3.6 & 9.8 & $<.3$ & 3.6 \\
\hline$<0.02$ & $<0.02$ & $<0.02$ & 0.04 & $<0.02$ & $<0.02$ \\
\hline
\end{tabular}




\section{DISSOEVET ORECEI}

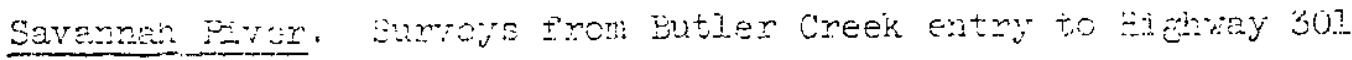
bridge are race esci cuarter to obtain dissolied oxyen profiles. The followirg table compares ate obtainea on lpril s and jure liz under comitions of righ eni normal flows; resnectively. River water tempenetures vere higizer on June 13 than on Aoril 4 . The dissolved oxyer content during both periods was romel for b. stream not adversely affected by pollution. The Spirit Creek dati reflect oxygen cortent of a thin layer of whilluted creek water, sampled 100 jards downstream from the nouth of Spirit Creek. Three hundrea yawis cownstream, the oxygen content of the creek and river water mixture was nomal. River water oxyger content during both periods was slightiy depressed adjacent to the Plant due to increased water temperatures. Sampling locations are showr in figure 11.

\section{Location}

Butler Creek

Spjuzt Creek

Silver Bluff

Gray's Ianuing

$S R 2$

Hancock Landing

Griffin's Landing

Brigham's Laraing

Steel Creek

Iittle 닉 I Inding

Lower Three Runs

Jchnson's Landing

U. S. 301
Water r'emp, Dissolved Oxysen,

\begin{tabular}{|c|c|c|c|c|c|}
\hline de? & , & p & $n$ & Eat & Eicoll \\
\hline$4 \longdiv { 4 }$ & $6 / 13$ & $4 \sqrt{4}$ & $6 / 13$ & 4,4 & $0 / 13$ \\
\hline 1.3 & 18 & 10.4 & 7.5 & 38 & 83 \\
\hline 33 & 19 & 4.7 & 4.4 & $\leq 4$ & 47 \\
\hline 13 & 18 & 10.4 & 8.4 & 98 & 88 \\
\hline 13 & 18 & 10.4 & 8.? & 88 & 85 \\
\hline 24 & 18 & 10.2 & 8.2 & 97 & 80 \\
\hline 14 & 19 & 9.3 & 7.5 & 89 & 80 \\
\hline 13 & 20 & 9.3 & 7.5 & 88 & 82 \\
\hline 13 & 20 & 9.0 & 7.5 & 85 & 82 \\
\hline 1.3 & 25 & 9.0 & 6.7 & 85 & 80 \\
\hline 18 & 27 & 7.1 & 7.5 & 75 & 91 \\
\hline 14 & 23 & 8.5 & 7.1 & 82 & 82 \\
\hline 14 & 23 & 8.3 & 7.1 & 80 & 32 \\
\hline 14 & 23 & 9.0 & 7.1 & 87 & 82 \\
\hline
\end{tabular}




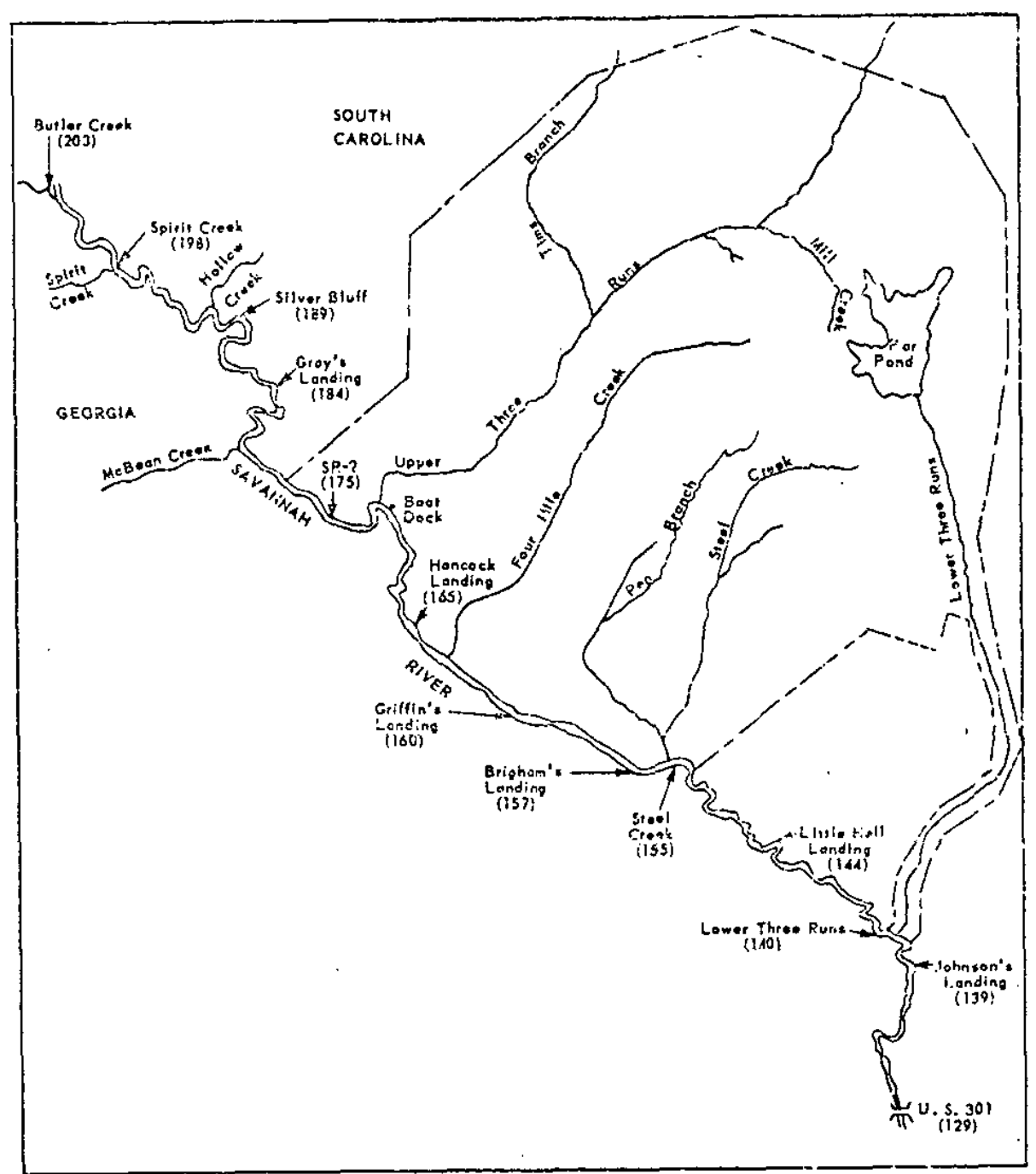

FIGURE 11. DISSOLVED OXYGEN SAMPLE POINTS ON THE SAVANNAY RIVER. Numbers in parenthosos ore river milos from Sovannoh, Georgia. 


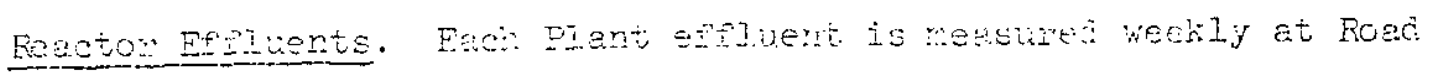

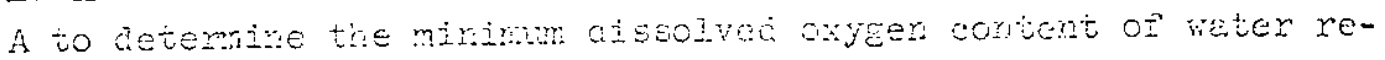
tumed to the river. Uper Tree kus is epmpled as a control. The mininum dissolved oxyen content of rater returned to the river vas ecequate to support diveree popilations of acuatic life.

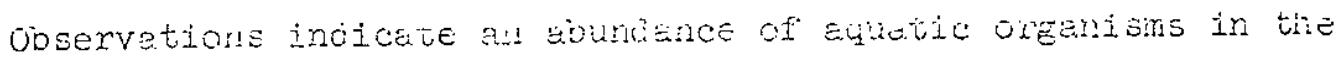
lower reaches of the effluent strecms and in the Savannai River.

\begin{tabular}{|c|c|c|c|c|c|c|}
\hline \multirow[b]{2}{*}{ Effluent } & \multicolumn{3}{|c|}{ yissolvez Oxysen, porm } & \multicolumn{3}{|c|}{ Fercent Saturstion } \\
\hline & Win & Ave & Pnov $\mathrm{AVg}$ & in & $A V B$ & Erey AVg \\
\hline Upper Tinee Runs & 7.8 & 9.3 & 8.6 & 7.8 & 81 & 91 \\
\hline Four thile Creek & 4.5 & 6.1 & 5.7 & 76 & 93 & 91 \\
\hline Pen Branci & 4.7 & 6.1 & 5.4 & 82 & 98 & 92 \\
\hline Steel Creek & 4.5 & 6.7 & 5.6 & 84 & 98 & 93 \\
\hline Lower Three Runs & 5.8 & 8.8 & 7.6 & 71 & 88 & 79 \\
\hline
\end{tabular}




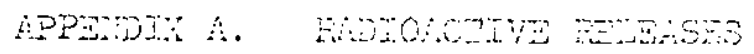

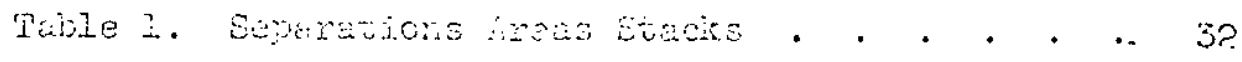

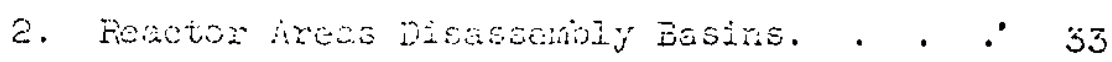

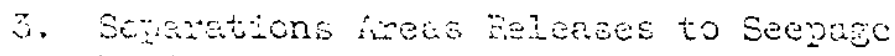

$$
\begin{aligned}
& \text { Basize . . . . . . . . . . . } 34
\end{aligned}
$$

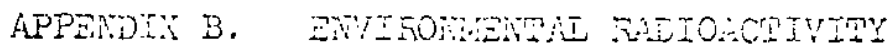

Trible 1. Roboactivity tritir . . . . . . . 35

2. Game Faciation jerels. . . . . . . 30

3. Facoactivity in Fankater , . . . 37

t. kaciodetivity in veretation , . . . . 38

5. Radiocotivity in Mir. . . . . . . 38

ó. Reitocetivity ils Piant irinking weter. . 39

7. Reciocotivity in Fublic Drinzing flater . 40

8. Radioactivity in Plant Streem vitex . . AI

9. Radocotivity in Plan Strean Wua . . . AR

10. Radioactivity in Savinabi Riven water. . 4.3

11. Radioactivity in Seepege Basin Water . . 44

12. Radioactivity in Ground Nater. . . . . 45

13. Raciodctivity in $\mathrm{F}$ and $\mathrm{H}$-Area Seepare Basin Wells . . . . . . . . . . 46 
Tabic J. Separations Areas Stuck Releases

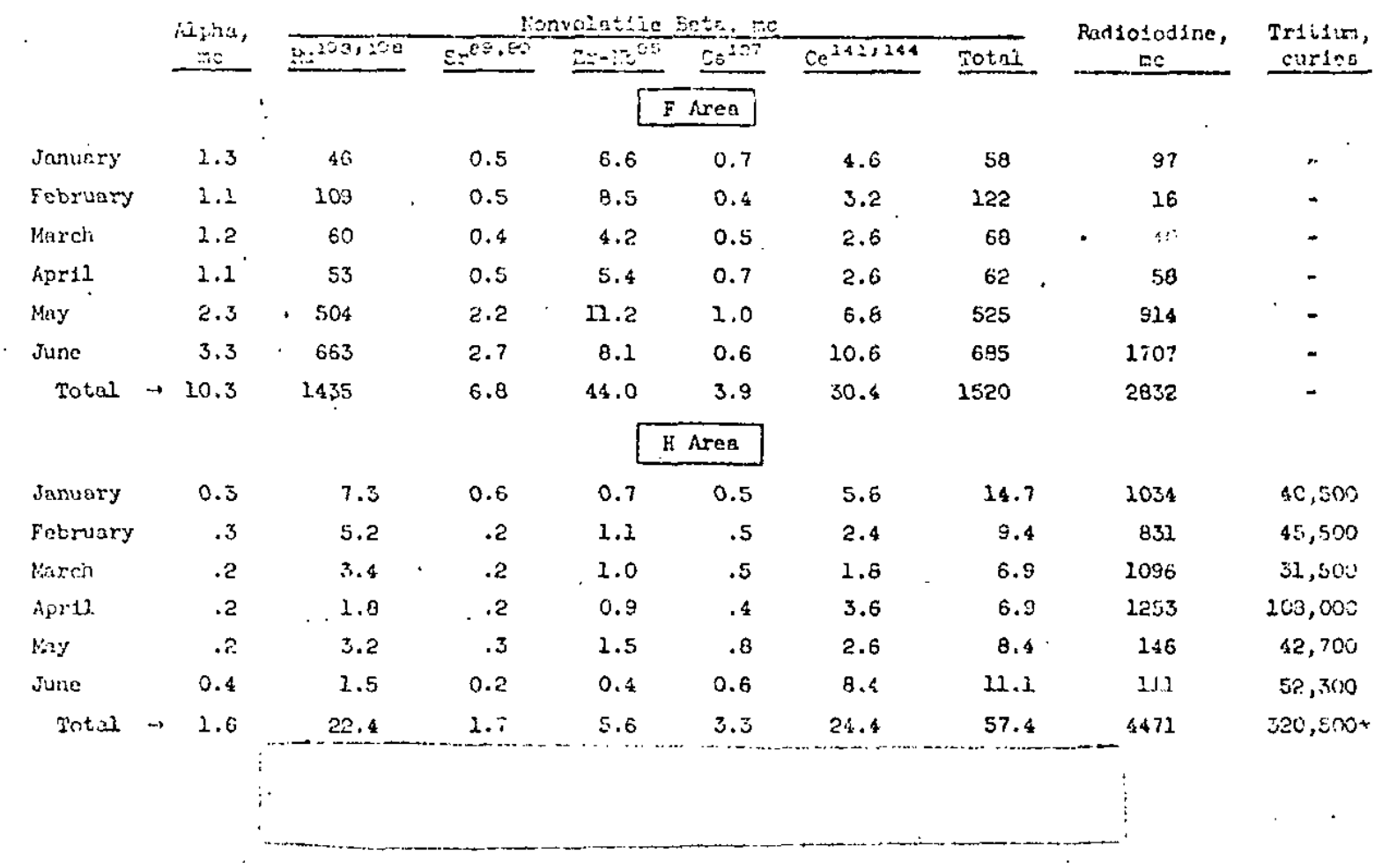


APPEWIX

Tále 2. Reactor Areas jisasemuly Basin nereases, curies

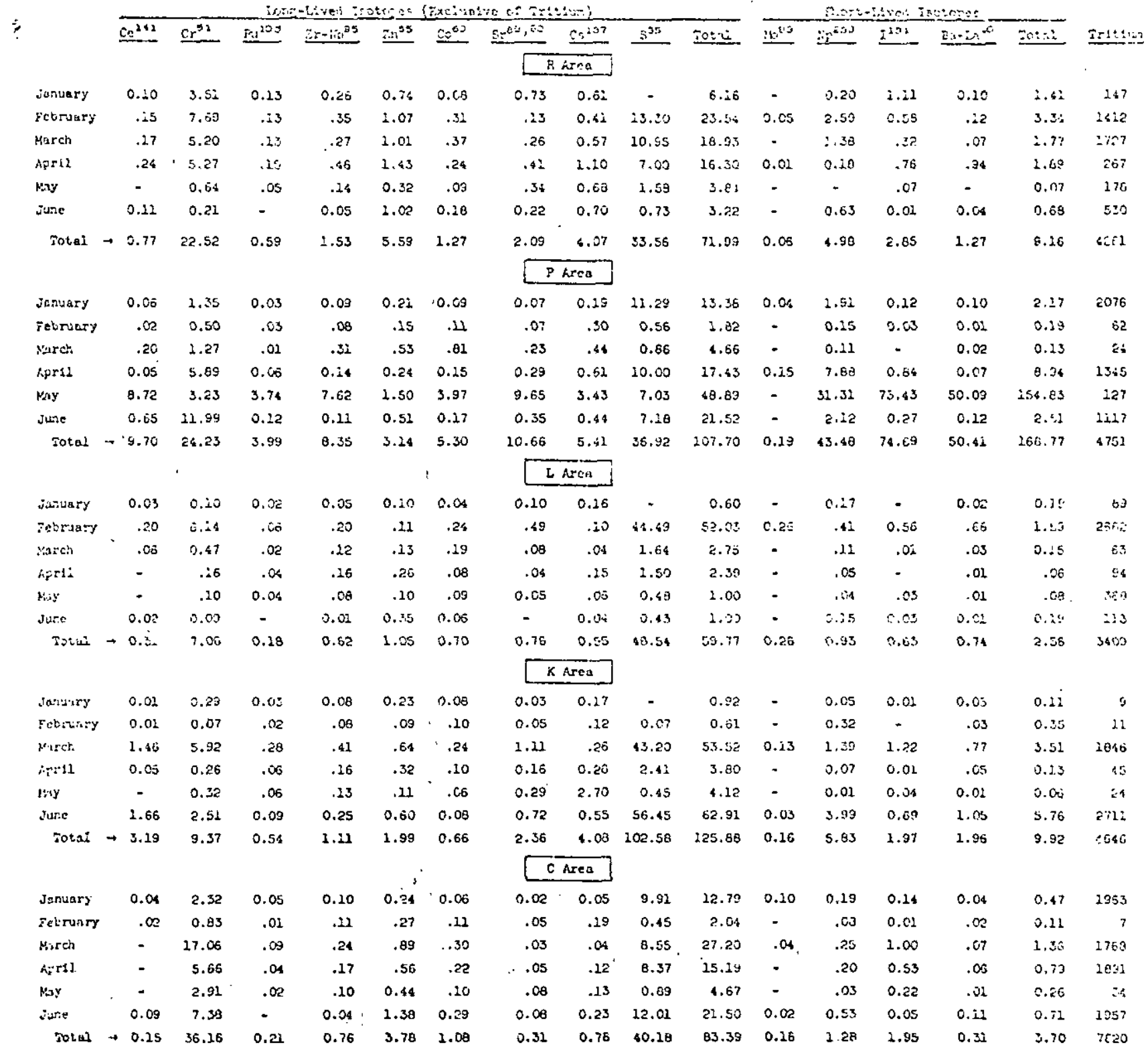


Table 3. Separations Aroa Peleases to Seepare Rasins

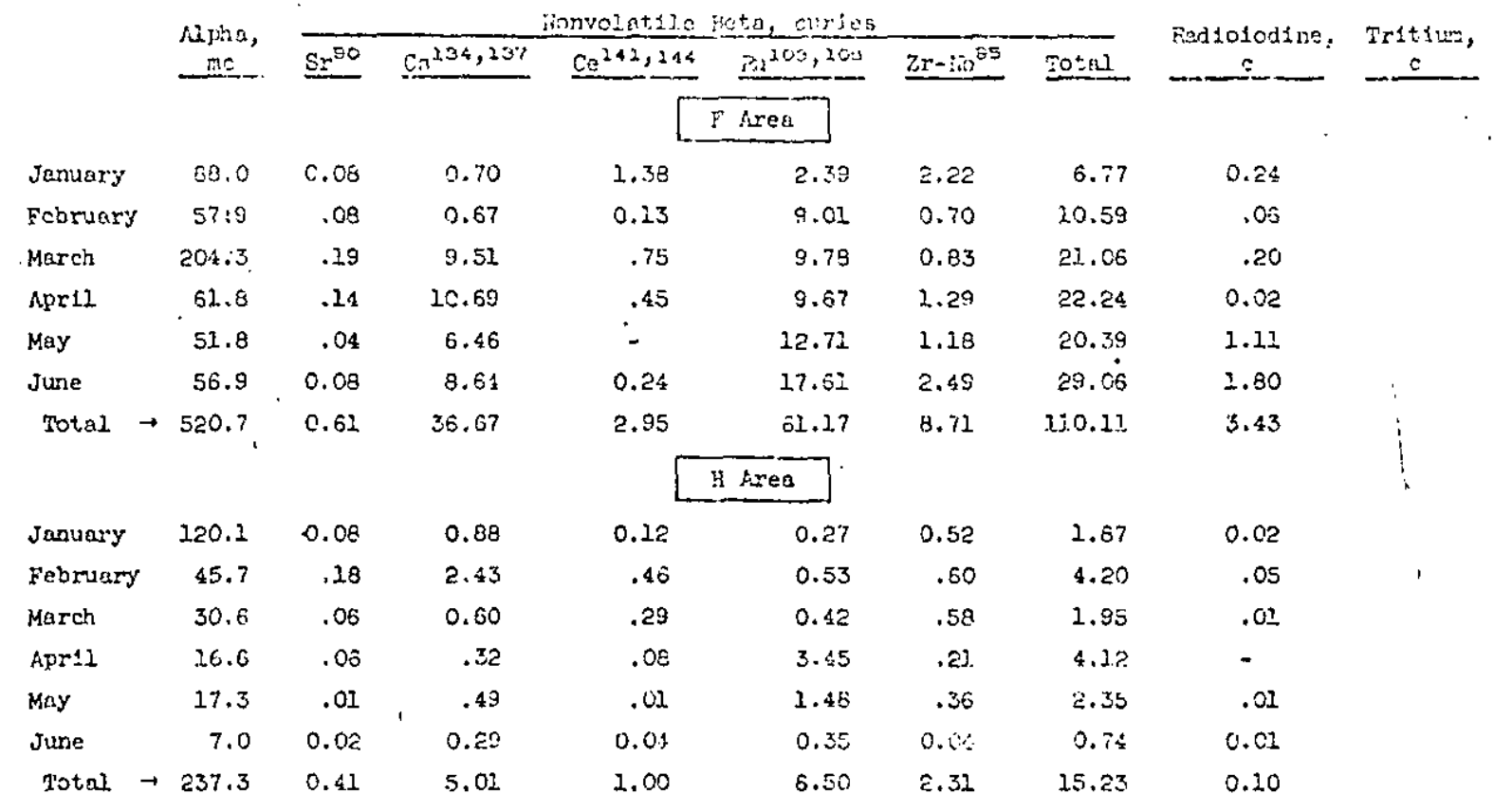


APPENDIX ¿

EIVIROMEITAL RATOACTIVTY

Table 1. Radioactivity in $4 i n, \mu \mu c / m^{3}$

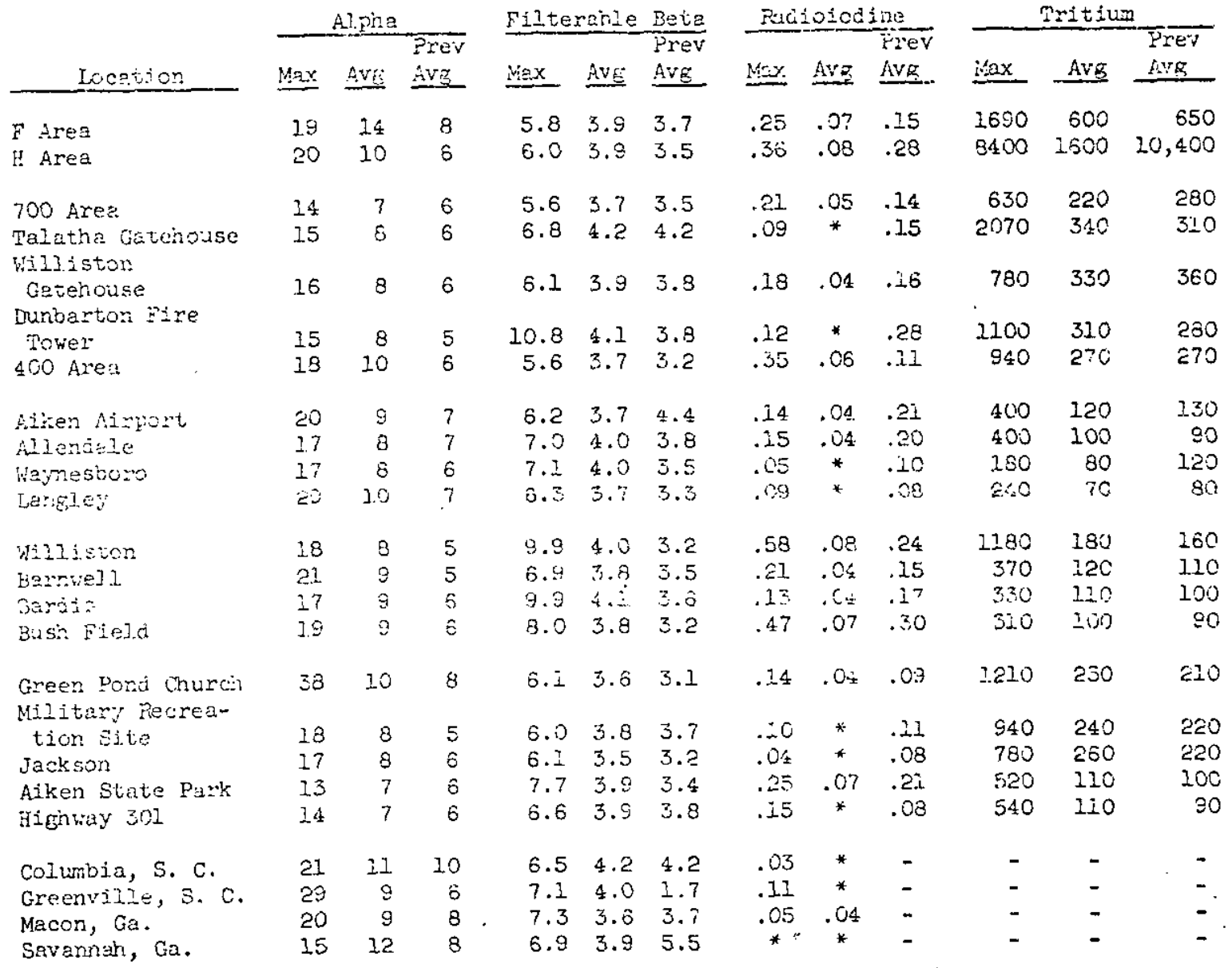

* Less tran sensitivity of analysis. 


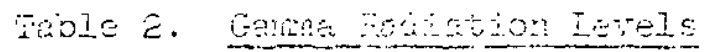

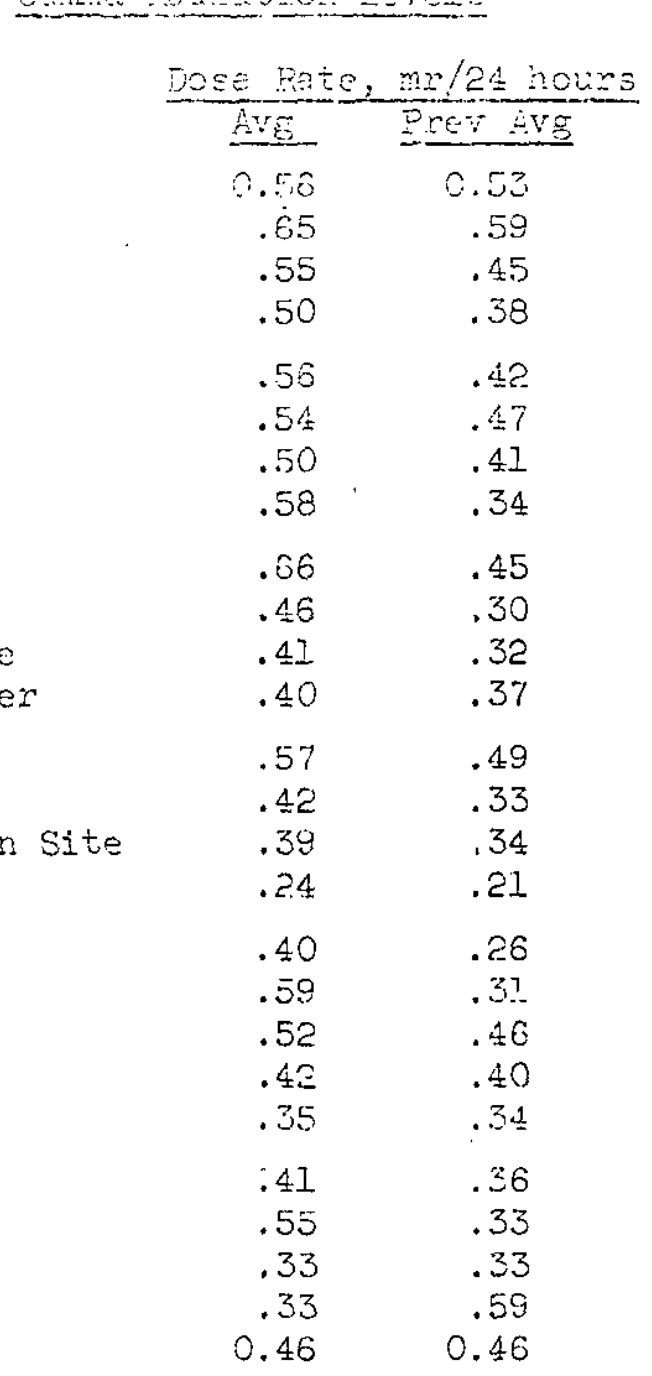

P Aree

$\exists$ Area

$R$ Area

P Area

L Area

K Anea

C Area

TC Area

$300 / 700$ Area

Talatna Gatenouse

Williston Gatenouse

Dunbarton Fire Tower

400 Area

Green Pond Church

Military Recreation Site

Jackson

Aiken Airport

Allendale

Waynesboro

Bush Fiela

Langley

Willistor

Barnwell

Sardis

Aiken State Pari

Highway 301 
Appinity 3

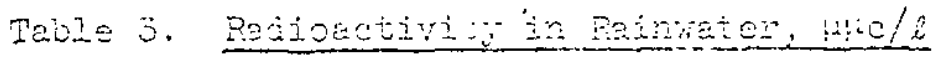

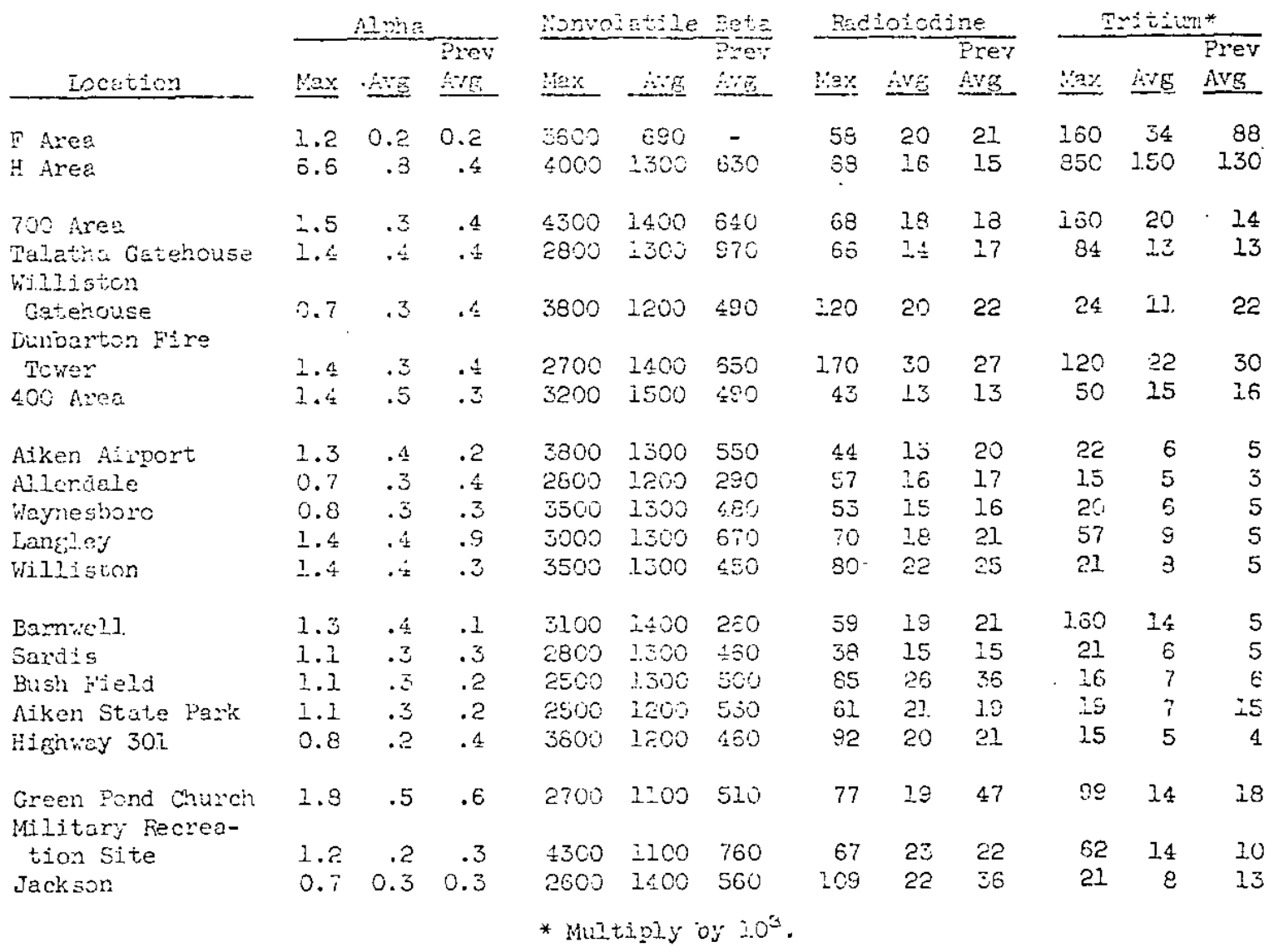




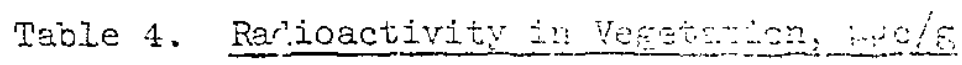

\begin{tabular}{|c|c|c|c|c|c|c|c|c|c|}
\hline & & pha & & Bonve & $3: i\}$ & Esta & Ba & $10 \div 00$ & $n e$ \\
\hline - Location & in: & $A \vee E$ & $\begin{array}{l}\text { Prev } \\
A \cdot \bar{q} \bar{g} \\
\end{array}$ & $y=x$ & $\because 2$ & $\begin{array}{l}\text { Prei } \\
3 y=8 \\
3\end{array}$ & $\operatorname{Men} x$ & $A B$ & $\begin{array}{l}\text { PNeV } \\
\text { SYE }\end{array}$ \\
\hline $\begin{array}{l}\text { F Area } \\
\text { (at } 1 \text { mile racius) }\end{array}$ & 0.6 & 0.3 & 0.1 & 1100 & 350 & 23 & 8 & 6 & 3 \\
\hline $\begin{array}{l}\text { H Area } \\
(\text { at } 1 \text { mile raóilis })\end{array}$ & .6 & .3 & ...1 & 1.200 & 510 & 50 & 12 & 7 & 3 \\
\hline Plant Perimeter & .9 & .2 & .1 & 1000 & 230 & 77 & 12 & 7 & 4 \\
\hline 25 Mile Radius & 0.8 & 0.2 & 0.1 & 1800 & 320 & 77 & 10 & 7 & 3 \\
\hline
\end{tabular}

Table 5. Radioactivity in Milk, $\mu \mu \mathrm{c} / 2$

$\frac{\text { Radioiodine }}{\text { Max Avg Prev-Avg }}$ Mritium

Farm Cow

$\begin{array}{lrrrrrc}\text { Pleasant Mount } & 52 & 10 & 210 & 10,000 & 5000 & * \\ \text { Snelling } & 51 & 15 & 88 & 14,000 & 8000 & 6000 \\ \text { Talatha } & 22 & 8 & 130 & 8,000 & 6000 & 6000\end{array}$

Dairy

$\begin{array}{lrrrrrr}\text { Aiken } & 30 & 8 & 80 & 12,000 & 4000 & * \\ \text { Alleildale } & 12 & 6 & - & 11,000 & 4000 & - \\ \text { Barnwell } & 43 & 9 & - & 9,000 & 4000 & - \\ \text { North Augusta } & 17 & 7 & 54 & 9,000 & 4000 & 4000 \\ \text { Waynesboro, Ga. } & 30 & 7 & - & 11,000 & 4000 & - \\ \text { Williston } & 9 & 6 & - & 10,000 & 4000 & -\end{array}$

Farm Cow

Small Dairy

Major Distributor

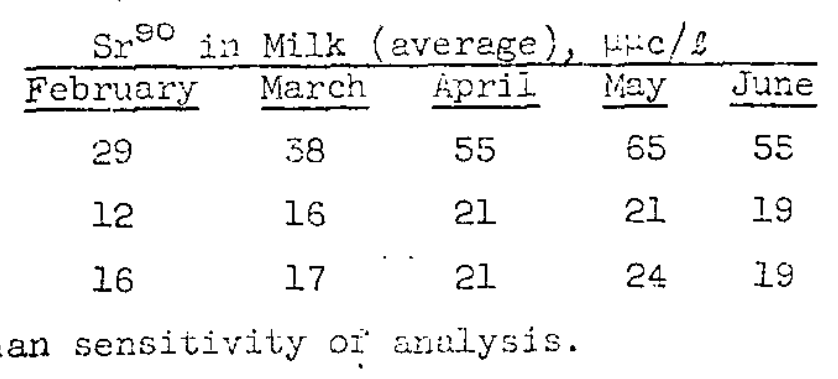


APFENDIX B

Table 6. Radioactivity in Plant Drinking Water, $\mu \mu \mathrm{c} / 2$

\begin{tabular}{|c|c|c|c|c|c|c|}
\hline Locetion & Max & Avg & $\mathrm{Avg}$ & $\operatorname{Max}$ & Avg & Ave \\
\hline F Area & 14 & 7.4 & 5.7 & 35 & 23 & 20 \\
\hline H Area & 8.0 & 5.9 & 7.1 & 27 & 18 & $2 I$ \\
\hline $3 / 700$ Area & 1.6 & 1.0 & 1.2 & 14 & 8 & 5 \\
\hline 400 Area & 2.5 & 1.9 & 1.4 & 32 & 14 & 10 \\
\hline $\mathrm{CNX}$ & 3.7 & 1.8 & 1.0 & 16 & 10 & 11 \\
\hline Pump House I & 1.0 & 0.7 & 0.3 & 6 & S & 14 \\
\hline Pump House 2 & 0.6 & 0.5 & 0.6 & 6 & 4 & 7 \\
\hline R Area & 0.7 & 0.4 & 0.3 & 12 & 5 & 5 \\
\hline $\mathrm{P}$ & 1.0 & 0.7 & 0.8 & 14 & 7 & 6 \\
\hline L & 0.3 & * & * & 33 & 1.6 & 5 \\
\hline $\mathrm{K}$ & 0.3 & 0.2 & 0.3 & 37 & .16 & 5 \\
\hline $\mathrm{C}$ & 0.4 & 0.2 & 0.2 & 24 & 17 & 7 \\
\hline Par Pond - Pump House & 0.5 & 0.3 & 0.2 & 9 & 5 & 9 \\
\hline TC Area & 9.7 & 3.9 & 4.4 & 22 & 13 & 14 \\
\hline Classification Yards & 1.2 & 0.9 & 0.9 & 8 & 5 & 5 \\
\hline Central Bn:ops & 0.0 & 0.5 & 0.8 & 7 & 5 & 4 \\
\hline Barricade 1 & 1.9 & 1.2 & 1.4 & 10 & 8 & 13 \\
\hline 2 & 37 & 32 & .34 & 69 & 55 & 50 \\
\hline 3 & 0.4 & 0.4 & 0.2 & 8 & 7 & 4 \\
\hline 4. & 4.0 & 4.0 & 4.0 & 13 & 12 & 8 \\
\hline 5 & * & * & * & 10 & 7 & * \\
\hline Robbins Station & 0.5 & 0.4 & 0.4 & 10 & 6 & 4 \\
\hline Donora Station Well & 0.4 & 0.2 & 0.4 & II & 4 & 5 \\
\hline
\end{tabular}

* Less than sensitivity of analysis. 


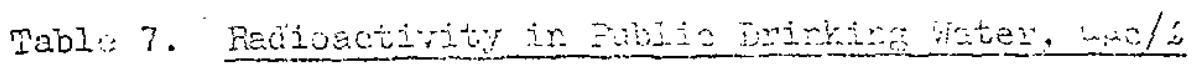

\begin{tabular}{|c|c|c|c|c|c|c|}
\hline \multirow[b]{2}{*}{ Location } & \multicolumn{3}{|c|}{ ipina } & \multicolumn{3}{|c|}{ Norvolatio Bota } \\
\hline & 20 & $A V$ & $\begin{array}{l}\text { Prev } \\
\text { Mre }\end{array}$ & $\underline{M a x}$ & 证 & $\begin{array}{l}3 x \in \mathrm{v} \\
\because \\
\end{array}$ \\
\hline Allendale & 0.2 & * & * & 15 & 5 & 4 \\
\hline Sardis & 0.2 & *- & $*$ & .11. & 6 & 5 \\
\hline Waynesboro & 0.3 & * & * & 37 & 38 & 6 \\
\hline Augusta & 0.3 & $*$ & 0.2 & 15 & 11 & 7 \\
\hline North August? & 0.4 & 0.2 & 0.2 & 27 & 1.3 & 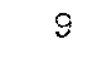 \\
\hline Clearwater & 0.5 & 0.2 & 0.2 & 22 & 14 & 8 \\
\hline Bath & 4.3 & 3.4 & 2.3 & 17 & 12 & .10 \\
\hline Langley & 2.1 & 2.0 & 1.9 & 17 & 11 & 9 \\
\hline Jackson & 0.5 & 4.8 & 4.2 & 30 & 16 & 15 \\
\hline New Elizenton & 1.7 & 0.9 & 0.7 & 13 & 5 & 6 \\
\hline Aiken & 3.8 & 2.8 & 2.0 & 12 & 8 & 8 \\
\hline Williston & 2.3 & 1.4 & 1.6 & 18 & 10 & 8 \\
\hline Blackville & 0.8 & 0.3 & 0.2 & 11 & 5 & 5 \\
\hline Barnwell & 0.5 & 0.2 & 0.2 & 15 & 6 & 7 \\
\hline
\end{tabular}

* Less than sensitivity of analysis. 


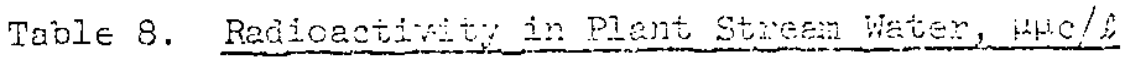

\begin{tabular}{|c|c|c|c|c|c|c|c|c|c|c|}
\hline & \multirow{2}{*}{\multicolumn{3}{|c|}{ 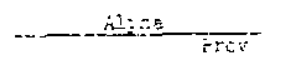 }} & \multicolumn{3}{|c|}{$\therefore$ arontine $5: a$} & \multicolumn{3}{|c|}{$7 x+=i v x^{*}$} \\
\hline & & & & & $\therefore=$ & $s$ & 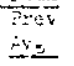 & $\because \because$ & $\underline{-2}$ & $\begin{array}{l}7 \mathrm{Fe} \\
\mathrm{n}-\mathrm{s}\end{array}$ \\
\hline & & \multicolumn{9}{|c|}{ 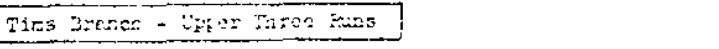 } \\
\hline 1 & Ecntrol & 8.3 & 2.2 & 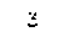 & 120 & 5 & 10 & . & - & - \\
\hline 2 & F-Artet Stom Gawer: & 150 & 212 & $2 z$ & 4400 & 2400 & $\epsilon \mathrm{Si}_{0}$ & - & - & - \\
\hline 3 & 700 -Area Efficht & 1300 & 140 & 48 & 3000 & $\$ 30$ & 190 & 24 & 4 & 4 \\
\hline 4 & Z00-Área Exfluent & 602 & $\check{c} 80$ & 170 & 1200 & 520 & 430 & - & - & - \\
\hline 5 & Poad $C$ & 4.0 & 1.2 & 1 & 120 & 27 & 8 & - & - & - \\
\hline o & HWus zepluent, v Arsz & 17 & 3.8 & - & 77 & 18 & - & - & - & - \\
\hline \multirow[t]{2}{*}{7} & Boas A & 2.1 & 0.9 & 0.3 & 52 & 22 & 7 & 12 & 5 & 5 \\
\hline & \multicolumn{10}{|c|}{ Four w1le cretk } \\
\hline 3 & F-Area Effluent & 17.9 & 3.7 & 6.7 & 4400 & 1200 & 3400 & 34 & 8 & i: \\
\hline 9 & H-Area Efluent & 2.0 & 1.2 & 1.4 & 220 & 45 & 53 & 310 & 180 & 330 \\
\hline 20 & Fonas $C$ & 2.3 & 0.7 & 0.6 & 530 & ६⿴\zh11 & 180 & 300 & 200 & - \\
\hline \multirow[t]{2}{*}{11} & Poad $k$ & 0.6 & 0.3 & 0.3 & 720 & 120 & 230 & $3 \approx 0$ & 48 & $i 50$ \\
\hline & & & Pen & anch & & & & & & \\
\hline \multirow[t]{2}{*}{12} & Foed $A$ & 0.6 & $* *$ & 0.2 & 5700 & 540 & 120 & 900 & 75 & 52 \\
\hline & & & Steel 0 & resk & & & & & & \\
\hline \multirow[t]{2}{*}{23} & Road A & 0.5 & 0.2 & 0.3 & \pm 300 & $2: 0$ & 160 & 290 & 60 & 59 \\
\hline & & & Far: & and & & & $v$ & & & \\
\hline 15 & Flisp House ${ }^{\top}$ & 0.4 & ** & 0.2 & 270 & 140 & 74 & $5: 20$ & 200 & $=0$ \\
\hline \multirow[t]{2}{*}{16} & P-irea cooling Weter & 0.3 & 0.2 & 0.2 & 130 & 240 & 73 & 92 & 85 & 75 \\
\hline & & & ower fis & et: nuts & & & & & & \\
\hline 17 & Petterson's $\mathrm{kill}$ & 0.4 & 0.2 & 0.2 & 150 & ¿s & 51 & 92 & 59 & $\$ 5$ \\
\hline A & & 0.6 & * & 0.2 & \$6 & Eo & 3 & 52 & 34 & \\
\hline
\end{tabular}

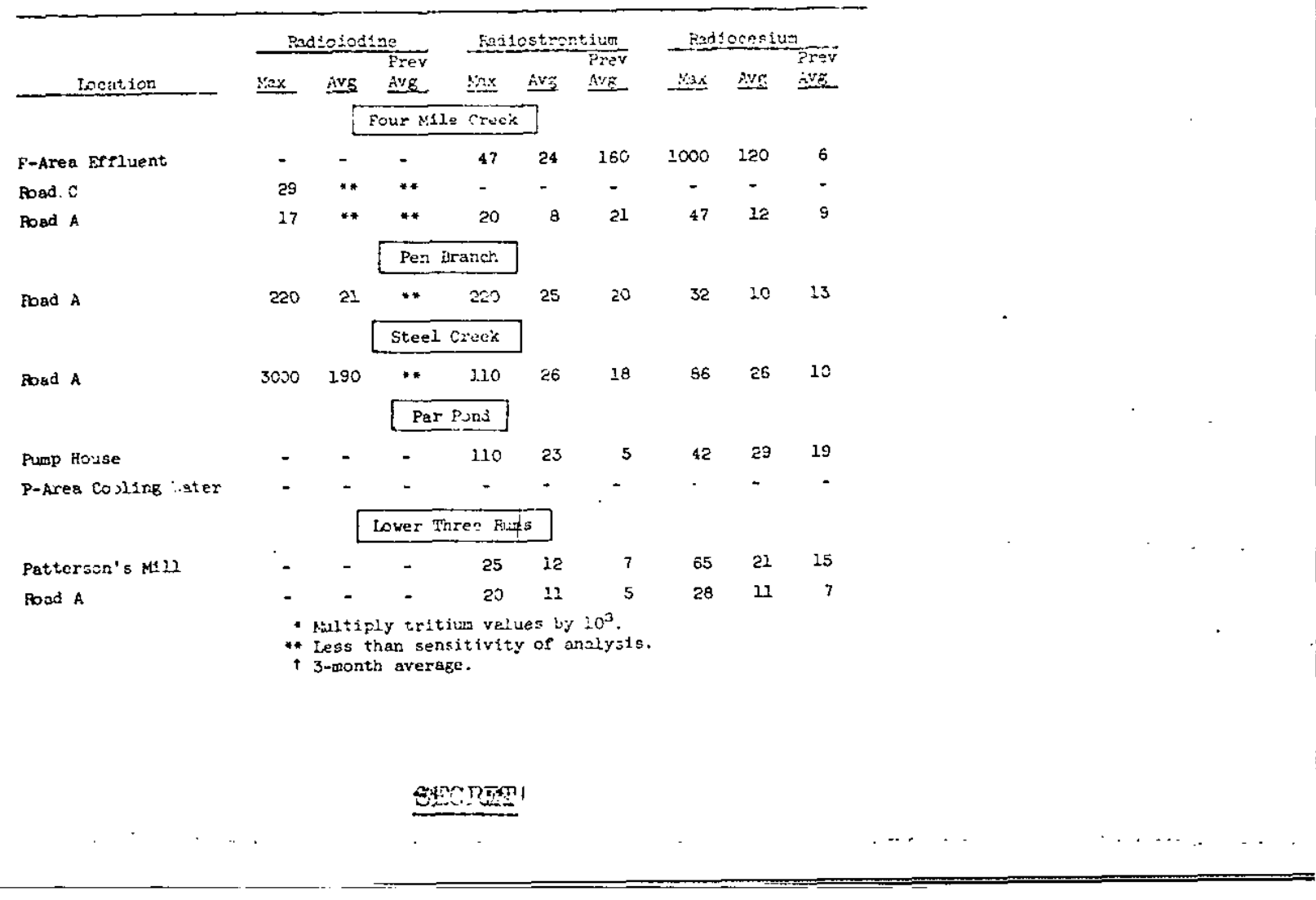


Table 9. Badioactivity in Plant Stream Mad, $\mu \mu c / g$

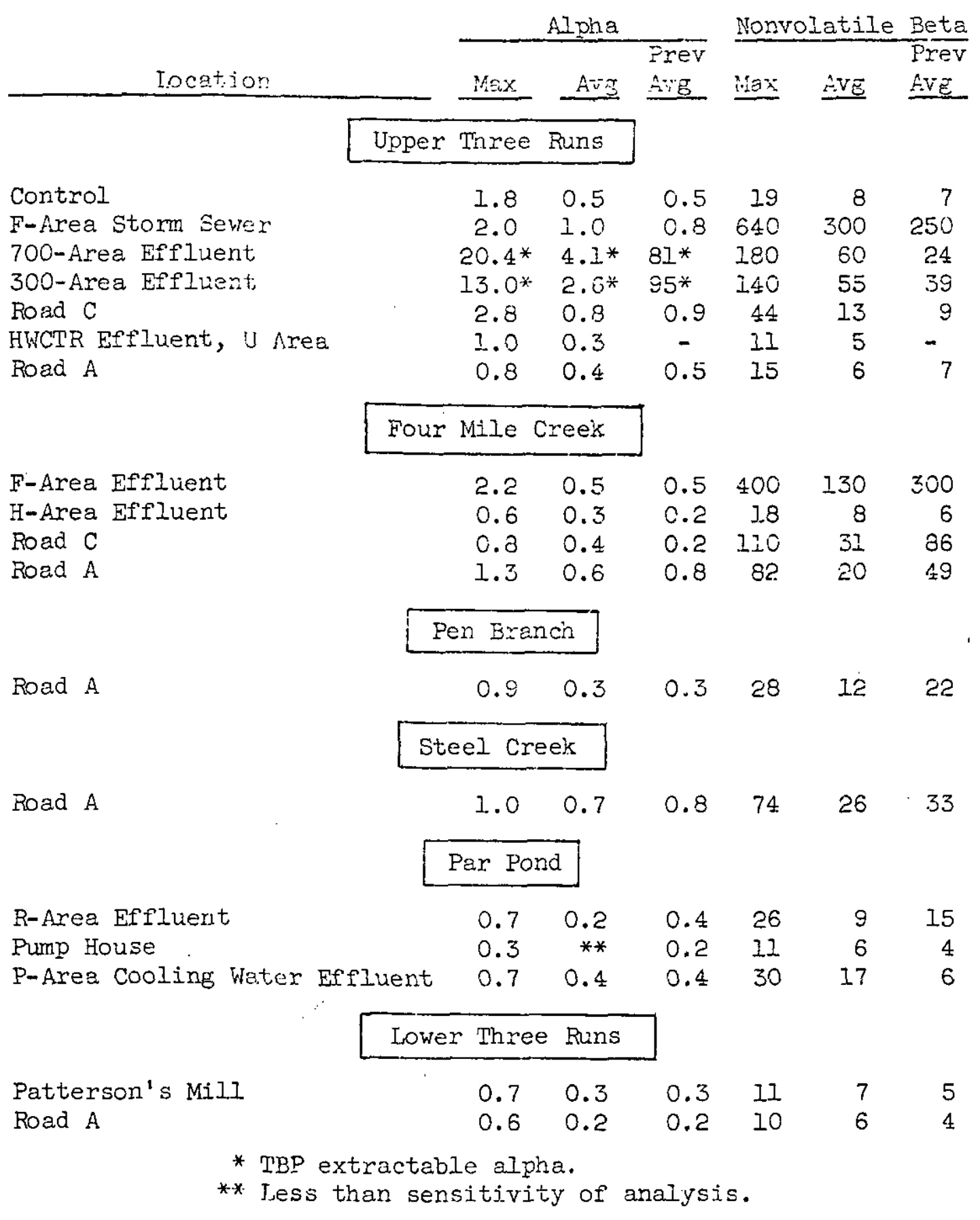




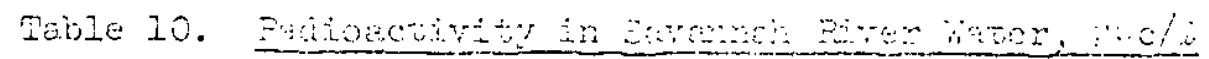

\begin{tabular}{|c|c|c|c|c|c|c|c|c|c|}
\hline \multirow[b]{2}{*}{ Iocasion } & \multicolumn{3}{|c|}{ Aina } & \multicolumn{2}{|c|}{ monvoletis } & Bota & \multicolumn{3}{|c|}{ Mritur } \\
\hline & NEX & AYE & $\begin{array}{l}\text { Frev } \\
\text { Ano }\end{array}$ & $\max$ & $\dot{1 V a}$ & 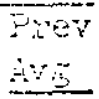 & $10 x$ & $A Y B$ & 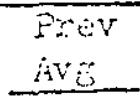 \\
\hline 2 & 0.9 & 0.5 & 0.2 & $9 \%$ & 30 & 8 & 9,000 & 2000 & 3,000 \\
\hline 3 & 1.0 & .2 & .2 & 72 & 30 & 7 & - & - & - \\
\hline 5 & 0.4 & .2 & $\because$ & 210 & 37 & 25 & - & - & - \\
\hline 8 & .7 & .2 & .2 & 260 & 62 & 45 & -. & - & - \\
\hline 9 & .6 & .2 & .2 & 97 & 52 & 29 & - & - & - \\
\hline 10 & .6 & .2 & .2 & 150 & 52 & 29 & 20,000 & 9000 & 14,000 \\
\hline 11 & 0.9 & 0.2 & 0.3 & 160 & 48 & 28 & 23,000 & 9000 & 25,000 \\
\hline
\end{tabular}

\begin{tabular}{|c|c|c|c|c|c|c|c|c|c|}
\hline \multirow[b]{3}{*}{ Location } & \multicolumn{3}{|c|}{ Radionodine } & \multicolumn{3}{|c|}{ Radiostrontium } & \multicolumn{3}{|c|}{ Raciocesium } \\
\hline & & & $\overline{\text { Prev }}$ & & & Prev & & & $\overline{\text { Prev }}$ \\
\hline & $\underline{\max }$ & Avg & AVE & $\operatorname{Max}$ & $\mathrm{Avg}$ & AVE & ivax & AvE & $\hat{A V E}$ \\
\hline 2 & - & - & - & - & - & - & .. & .. & ـ \\
\hline 8 & - & - & - & 24 & 8 & * & 13 & 5 & * \\
\hline 9 & - & - & - & 20 & 9 & * & 12 & 4 & $*$ \\
\hline 10 & 130 & 11 & $*$ & 19 & 7 & * & 19 & 3 & * \\
\hline 31 & - & - & - & 14 & 7 & * & 10 & 5 & $\%$ \\
\hline
\end{tabular}

\begin{tabular}{|c|c|c|c|c|c|c|}
\hline \multirow[b]{2}{*}{ Iocation } & \multicolumn{3}{|c|}{ TBP Extractaule Alpia } & \multicolumn{3}{|c|}{ Nonvolatile Eetra } \\
\hline & $\underline{\operatorname{Max}}$ & AVE & $\begin{array}{l}\text { Prev } \\
\text { Avg }\end{array}$ & Max & Avg & $\begin{array}{l}\text { Prev } \\
\text { Avg }\end{array}$ \\
\hline 2 & 3.8 & 2.5 & 1.3 & 29 & 18 & 15 \\
\hline 3 & 4.7 & 2.3 & 1.5 & 69 & 22 & 14 \\
\hline 5 & 2.7 & 2.0 & 1.4 & $4 \mathrm{C}$ & 23 & 17 \\
\hline 8 & 3.0 & 2.3 & 1.5 & 35 & 16 & 15 \\
\hline$\vartheta$ & 3.0 & 2.2 & 2.0 & 25 & 25 & 13 \\
\hline 10 & 4.4 & 2.1 & 2.]. & 42 & 20 & 15 \\
\hline 11 & 4.9 & 2.0 & 1.1 & 16 & 6 & 7 \\
\hline
\end{tabular}




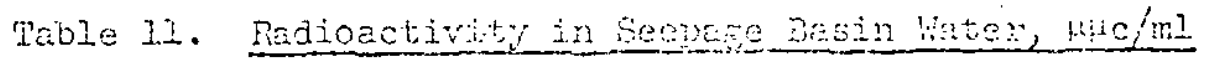

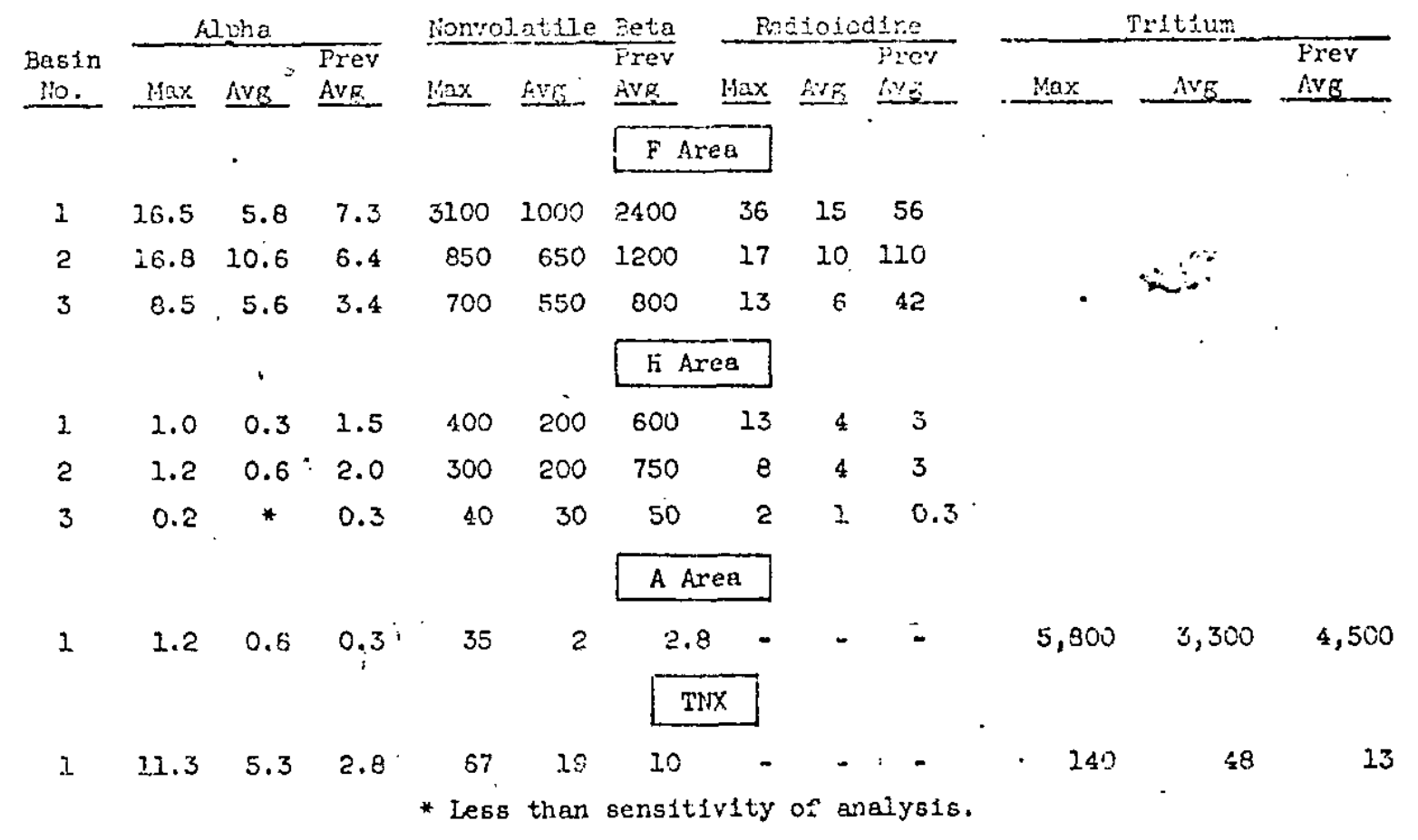




\section{APPENDIX $B$}

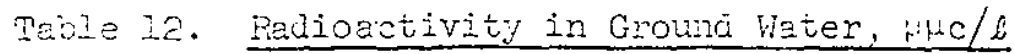

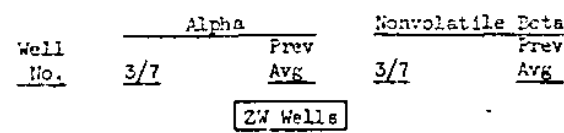

$\begin{array}{rrrrr}2 & 0.6 & 0.6 & 5 & 7 \\ 2 & 0.6 & .4 & 15 & 20 \\ 3 & 1.0 & .5 & 0 & 7 \\ 4 & 1.0 & .7 & 11 & 8 \\ 5 & 0.4 & .6 & 12 & 7 \\ 6 & .6 & .3 & 7 & 7 \\ 7 & .2 & .4 & 8 & 7 \\ 8 & .4 & .4 & 7 & 5 \\ 9 & .1 & .2 & 7 & * \\ 10 & 0.4 & 0.7 & 6 & 1.1 \\ & & \text { Burial Ground Wo11s }\end{array}$

\begin{tabular}{|c|c|c|c|c|c|c|}
\hline & $\underline{M a x}$ & Avg & & Max & $\underline{\underline{A}} \mathrm{R}$ & \\
\hline 1 & 0.9 & 0.4 & 0.2 & 14 & 9 & $\theta$ \\
\hline 2 & 0.5 & .2 & .3 & 10 & 8 & 11 \\
\hline 3 & 0.4 & .3 & .2 & 17 & 7 & 7 \\
\hline 4 & 1.3 & .7 & .4 & 2.1 & 8 & 10 \\
\hline 5 & 0.7 & .3 & .2 & 12 & 8 & 6 \\
\hline 6 & 0.6 & .2 & .3 & 46 & 22 & 12 \\
\hline 7 & 0.2 & .1 & .2 & 26 & 23 & 9 \\
\hline a & 1.4 & .7 &.$?$ & 20 & 9 & 15 \\
\hline 9 & 0.8 & .5 & 0.3 & 18 & 3 & 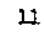 \\
\hline 12 & 1.2 & 0.7 & - & 29 & 12 & - \\
\hline 18 & 3.8 & 2.4 & - & 53 & 13 & - \\
\hline
\end{tabular}

Tritium in Ground Water, $\mu \mu \mathrm{c} / \mathrm{ml}$

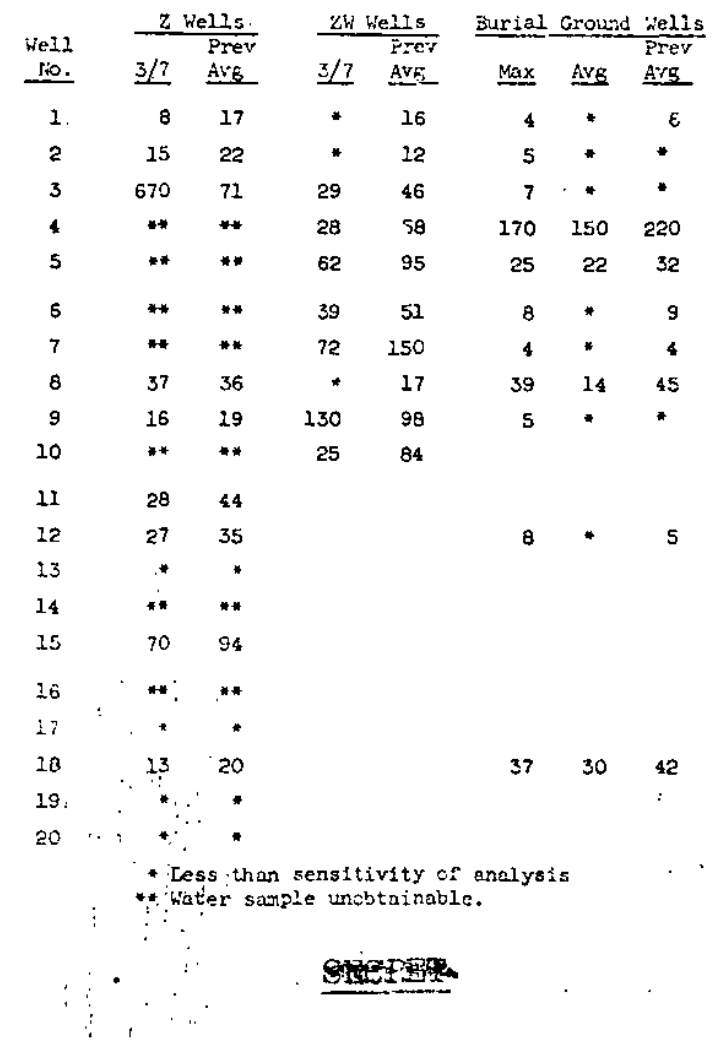


Table 13. Radioactivity in $F$ and $H$-Area Seepage Basin vieIIs, ${ }^{2}$ ic/liter

\begin{tabular}{|c|c|c|c|c|c|c|c|c|c|c|c|c|c|c|}
\hline & & & & Alphe & & Nor: & volatile $\mathrm{Be}$ & & & Lostront & & & $x+1 \leq x$ & \\
\hline & $\begin{array}{l}\text { kell } \\
\forall 0 .\end{array}$ & $\begin{array}{c}\text { Distance frot } \\
5 \sin 2 \mathrm{f}\end{array}$ & Max & $\mathrm{Av} 5$ & $\begin{array}{l}\text { Prev } \\
\text { Avg } \\
\end{array}$ & $\operatorname{Max}$ & Avg & $\begin{array}{l}\text { Prev } \\
\text { Avrz }\end{array}$ & $\operatorname{Max}$ & AVB & $\begin{array}{l}\text { Prev } \\
\text { Avg } \\
\end{array}$ & $\operatorname{tax}$ & Avs & $\begin{array}{l}\text { Prev } \\
\text { Avg }\end{array}$ \\
\hline & & & & & & & F Area & & & & & & & \\
\hline & $1 *$ & 34 & 3300 & 930 & 780 & 300,000 & 100,000 & 83,000 & 67,000 & 23,000 & 5,200 & 50 & 47 & 97 \\
\hline & $\hat{\imath}$ & 5 & 1.5 & 0.8 & 0.4 & 190 & 140 & 200 & - & - & - & 44 & 35 & 38 \\
\hline & 3 & 29 & 0.7 & 0.4 & 0.4 & 390 & 280 & 420 & - & - & - & 64 & $5 \tilde{5}$ & 75 \\
\hline & 4 & 73 & 0.4 & 0.2 & 0.2 & 1,100 & 830 & 490 & - & - & .. & 54 & 50 & 110 \\
\hline & 5 & 24 & 0.5 & 0.1 & 2.6 & 2,600 & 2,200 & 2,100 & - & - & - & 60 & 59 & 61 \\
\hline 1 & 6 & $\epsilon$ & 580 & 410 & 660 & 90,000 & 63,000 & 77,000 & 41,000 & 20,000 & 22,000 & 1.20 & 68 & 220 \\
\hline 12 & 7 & 46 & 750 & 470 & 620 & ةl,000 & 27,000 & $1 \hat{c} 0,000$ & 42,000 & 14,000 & 43,000 & 76 & 37 & 85 \\
\hline & 8 & 63 & 1.0 & 0.8 & 0.8 & 76 & 50 & 31 & - & - & - & 10 & 8 & 8 \\
\hline & 9 & 150 & 0.9 & 0.5 & 0.5 & 35 & 17 & $I I$ & - & - & - & 2 & 2 & 4 \\
\hline & 10 & 9 & 7800 & 4200 & 380 & 53,000 & 41,000 & 450,000 & 50,000 & 22,000 & 130,000 & 210 & 75 & 71 \\
\hline$\gamma$ & 11 & 9 & 1.9 & 1.2 & a... & 240 & 110 & 38 & - & - & - & 23 & 14 & 6 \\
\hline & $12 *$ & 29 & 8000 & 4600 & 120 & 53,000 & 40,000 & 160,000 & 33,000 & 20,000 & 22,000 & 100 & $7 \leftarrow$ & 66 \\
\hline & $13 *$ & 58 & 1300 & 350 & - & 310,000 & 190,000 & - & 29,000 & 21,000 & - & 100 & 5 & - \\
\hline & . & & & & & & ta Areg & & & & & & & \\
\hline & 1 & 24 & 110 & 50 & 32 & 16,000 & 5,400 & 9,500 & - & - & - & 25 & 10 & 34 \\
\hline & 2 & 25 & 0.7 & 0.9 & 0.4 & 1,300 & 270 & 56 & - & - & - & 53 & $4 i$ & 65 \\
\hline & 3 & 15 & 6.0 & 4.0 & 2.0 & 40,000 & 15,000 & $1 x, 000$ & - & - & - & 150 & 140 & 170 \\
\hline & 4 & 45 & 1.3 & 0.8 & 0.4 & \pm 60 & 100 & 70 & - & - & - & 5 & 3 & 2 \\
\hline & 5 & 13 & 1200 & 422 & 310 & 280,000 & 84,030 & 290,000 & 3,600 & 1,000 & 83,000 & 160 & 130 & 183 \\
\hline & 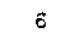 & 6 & 3.2 & 2.1 & 0.3 & 400 & 150 & 120 & - & - & - & 75 & $E \bar{J}$ & $7: 2$ \\
\hline & 7 & 66 & 0.5 & 0.3 & 0.4 & 85 & 50 & 55 & - & - & - & I2 & 6 & 2 \\
\hline & 8 & 28 & 0.3 & 0.1 & * & 380 & 120 & ilo & - & - & - & 19 & 17 & 21 \\
\hline & 9 & 78 & 0.5 & 0.2 & 0.2 & 420 & 120. & 38 & - & - & - & 13 & 12 & 15 \\
\hline & 10 & 19 & 0.3 & 0.1 & 0.2 & 110 & 75 & 72 & - & - & - & 13 & 11 & 20 \\
\hline & 11 & 79 & 0.3 & 0.2 & * & 150 & 79 & 130 & - & - & - & 35 & is & 28 \\
\hline & $A 37$ & 500 & 4.2 & 2.5 & 2.5 & 410 & 170 & 170 & iso & 130 & 98 & 57 & 42 & 40 \\
\hline & & & & & & $\begin{array}{l}\text { ells in } \\
\text { ult1ply }\end{array}$ & $\begin{array}{l}\text { perched wa } \\
\text { tritiun va }\end{array}$ & $\begin{array}{l}r \text { table. } \\
\text { es by } 10\end{array}$ & & & & & & \\
\hline
\end{tabular}

